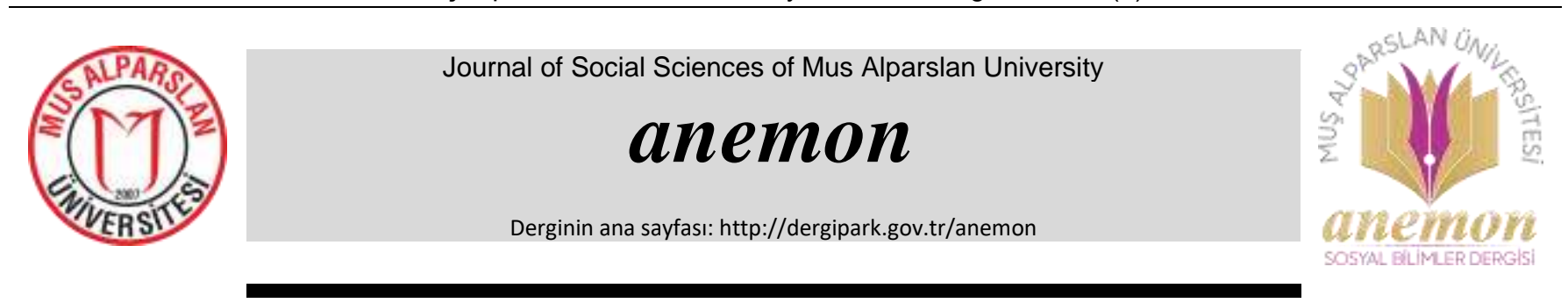

Araştırma Makalesi • Research Article

\title{
İç Kontrol Odaklı Girişimcilik Ölçeği Geçerlik ve Güvenirlik Çalışması*
}

\section{The Validity and Reliability Study Internal Locus Of Control Entrepreneurship Scale}

\author{
Münevver ÇETINN ${ }^{\text {a }}$ Duygu ŞALLI ${ }^{\text {b,*** }}$ \\ a Prof. Dr., Marmara Üniversitesi, Eğitim Bilimleri Bölümü, Istanbul/Türkiye. \\ ORCID: 0000-0002-1203-9098 \\ b Arş. Gör., Marmara Üniversitesi, Eğitim Bilimleri Bölümü, Istanbul/Türkiye \\ ORCID: 0000-0002-8126-7131
}

\begin{tabular}{l} 
MAKALE BİLGİSI \\
\hline Makale Geçmişi: \\
Başvuru tarihi: 01 Kasım 2020 \\
Düzeltme tarihi: 05 Şubat 2021 \\
Kabul tarihi: 13 Şubat 2021 \\
\hline Anahtar Kelimeler: \\
İç Kontrol Odağı \\
Girişimcilik \\
Yükseköğretim
\end{tabular}

\section{A R T I C LEINFO}

Article history:

Received 01 November 2020

Received in revised form 05 February 2021

Accepted 13 February 2021

\section{Keywords:}

Internal Locus of Control

Entrepreneurship

Higher Education
ÖZ

Girişimcilik, ülke ekonomilerinin büyümesine katkı sağlayan önemli faktörlerden biridir. Değişen koşullara uyum sağlayabilmek için akademisyenlerin bireysel olarak girişimciliğe yönelik çabalarının olduğu görülmektedir. Bu doğrultuda araştırmada akademisyenlerin iç kontrol odaklı girişimcilik eğilimlerini tespit edebilmeye yönelik geçerli ve güvenilir bir ölçek geliştirmek amaçlanmıştır. Araştırmanın evrenini Türkiye genelindeki üniversitelerde görev yapan akademisyenler oluşturmaktadır. Araştırmanın örneklemini basit seçkisiz örnekleme yöntemi ile seçilmiş olan 571 akademisyen oluşturmaktadır. Açımlayıcı faktör analizi sonucunda 7 faktör belirlenmiştir. İç kontrol odaklı girişimcilik ölçeğine ilişsin Cronbach Alpha katsayısı 0.894 değeri ile çok yüksek bulunmuş ve geliştirilmiş olan ölçeğin akademisyenlerin iç kontrol odaklı girişimcilik eğilimlerini ölçebilecek geçerliğe ve güvenirliğe sahip olduğu tespit edilmiştir.

\section{A B S T R A C T}

Entrepreneurship is one of the important factors contributing to the growth of national economies. It is seen that academics have individual efforts towards entrepreneurship in order to adapt to changing conditions. In this direction, it was aimed to develop a valid and reliable scale to determine the entrepreneurship tendencies of academicians internal locus of control.The research universe consists academics working in universities in Turkey. The sample of the study consists of 571 academicians selected from using simple random sampling method. As a result of factor analysis, 7 factors were determined. The Cronbach Alpha coefficient of the Internal Locus of Control Entrepreneurship scale was found to be very high with a value of 0.894 and it was determined that the scale developed has the validity and reliability to measure the entrepreneurship tendencies of academicians internal locus of control.

\section{Giriş}

$\mathrm{Bu}$ araştırma girişimciliği etkileyen önemli bir bileşen olan iç kontrol odaklı girişimcilik üzerine odaklanmaktadır. Bu doğrultuda araştırmanın problemi; bilginin üretilmesinde, aktarılmasında, bilimin ilerlemesinde önemli bir rol üstlenmiş olan akademisyenlerin iç kontrol odaklı girişimcilik eğilimlerini ölçmek için geçerli ve güvenilir bir ölçek geliştirmektir. Alanda girișimcilik ölçeği (İncik ve Uzun, 2017; Köybaşı ve Dönmez, 2017; Souzo, Santos, Lima, Cruz, Lezana \& Coelho, 2017; Yılmaz ve Sünbül,

2019) olmakla birlikte akademisyenler için geliştirilmiş herhangi bir girişimcilik ölçeğinin olmadığı görülmüştür. Aynı zamanda girişimcilik konusu, daha çok işletme alanında ele alındığı için eğitim alanında daha fazla çalışma

*Bu çalışma Marmara Üniversitesi ve Sabahattin Zaim ortak doktora programı Lisansüstü Eğitim Enstitüsü Eğitim Yönetimi ve Denetimi Anabilim Dalı'nda birinci yazarın danışmanlığında, ikinci yazar tarafından tanımlanmış "Yükseköğretimde İç Kontrol Odaklı Girişimcilik Eğilimlerinin İş Yaşam Dengesi ve Mesleki Motivasyon Bağlamında İncelenmesi” isimili doktora tezinden üretilmiştir.

**Sorumlu yazar/Corresponding author

e-posta: duygu.salli@marmara.edu.tr 
yapılmasının literatüre katkı sağlayacağı düşünülmektedir. Yabanc1 literatürde kontrol odağı ölçeği (Rotter,1966) bulunmaktadır. Yerli literatürde ise Rotter'ın kontrol odağı ölçeği temele alınarak daha kapsamlı olarak geliştirilmiş bir ölçeğe (Dağ, 2002) rastlanmıştır; fakat girişimcilik eğilimini iç kontrol odaklı bir perspektiften değerlendiren bir ölçeğe rastlanmamıştır. $\mathrm{Bu}$ araştırmada; literatürde ilk olarak girişimcilik konusuna iç kontrol odaklı bir çerçeveden bakılarak bu doğrultuda akademisyenlerin iç kontrol odaklı girişimcilik eğilimlerini değerlendirmek üzere bir ölçek geliştirmek amaçlanmıştır. $\mathrm{Bu}$ anlamda alana katkı sağlayacağı ve önemli olduğu düşünülmektedir.

Literatürde yansıtılan girişimciliğin kavramsallaştırılması, ekonomideki kökenlerinden başlayarak, çok çeşitli bilimsel disiplin ve bakış açılarından ortaya çıkmıştır (Bhole, 2007; Dayal, 2007; Hisrich, Peters \& Shepherd, 2016). Girişimci kavramının ortaya çıkışının ve gelişmesinin ekonomistler tarafindan yapıldığı kabul edilmektedir. Cantillon, Say, Schumpeter, Knight ve diğerleri, girişimciliğin doğasını, anlamını ve işlevlerini açıklama konusunda önemli bir rol oynamışlardır. Cantillon girişimcilik alanında söz sahibi olan ilk ekonomisttir ve girişimciliğin ekonomide gerçekleşen değişimlerden sorumlu olmasına dikkat çekmiştir. Cantillon'dan sonra J. B. Say girişimcinin ekonomi dışında yönetsel olarak bir rolü olduğunu vurgulamıştır (Ağça ve Yumuşakipek, 2015). Schumpeter ise girişimciliği yenilikçilik perspektifinden değerlendirmiştir. "Capitalism, Socialism and Democracy" isimli kitabında yeniliği; "yaratıcı yıkım" olarak nitelendirmiş ve girişimciliği ekonomik büyümeyi sürdüren yenilikçi bir güç olarak ele almıştır. Tarihsel sürece bakıldığında sanayi toplumundan bilgi toplumuna geçiş sürecinde ekonomik gelişmeyi belirleyen önemli etkenlerden birinin girişimcilik olduğu açıkça ortadadır (Bhole, 2007; Dayal, 2007; Hisrich vd., 2016). Bu anlamda girişimcilik, uluslararası alanda sürdürülebilir ekonomik gelişme ve rekabet avantajının kritik itici güçlerinden biri olarak kabul edilmektedir (Birch, 1987; Pathak \& Singh, 2007). Hatta birçok düşünürün Batı'nın gelişimini girişimciliğe bağladığı öne sürülmektedir (Pathak \& Singh, 2007). Mc Clelland'a göre, bir ülkede girişimcilerin en az $\% 2$ 'si varsa o ülke başarılı olarak kabul edilmektedir (Dewi \& Hamdani, 2019). Öyle ki girişimcilik, geri kalmış ekonomilerin yapılanmasında itici bir güç olarak görülürken, gelişmekte olan ekonomilerde temel yapılanmanın ötesinde kalkınma alanında, gelişmiş ekonomilerde ise dinamizmde temel yap1 taşı olarak değerlendirilmektedir (Naktiyok, 2004'ten akt: Ağca ve Yumuşakipek, 2015).

Büyümenin sınırlarının genişlemesi, ciddi çevresel ve ekolojik bozulma, uluslararası eşitsizlikler, işsizlik, artan finansal, ekonomik, politik istikrarsızlık, vb. etkenler sürdürülebilir, daha az kaynakla kalkınmayı zorunlu kılmıştır (Bhole, 2007; Dayal, 2007; Hisrich vd., 2016). Girişimcilik bu bağlamda özellikle son otuz yıldır, dünyanın şimdiye kadar tanık olduğu ekonomik kaynaklardan en güçlüsü olarak kendini göstermiştir. Girişimci büyümenin bir ülkeye muazzam bir ekonomik gelişme getirdiği böylece bir ülke ne kadar çok girişimciliğe sahip olursa, ekonominin o kadar gelişeceği fikri kabul edilmiştir (Dewi \& Hamdani, 2019). Girişimciliğin ve dolayısıyla girişimci bireylerin ekonomik anlamda yarattığı bu etki; girişimciliği daha net anlamak ve girişimcilikten fayda sağlama düşüncesi bu alandaki araştırmaların artmasını sağlamıştır (Paço \& Raposo, 2011).

Bir ülkenin kalkınması, gelişmesi ve büyümesi için girişimcilerin yetiştirilmesi önemlidir. Öyle ki girişimcilik, örgütlerin kurulmasında ve gelişmesinde olduğu kadar ülke kalkınmasında da rol oynayarak (Bhole, 2007; Dayal, 2007; Hisrich vd., 2016) çağdaş yaşamı şekillendiren kültürler arasındaki önemli bağlantıları da gizlemektedir. Bu sayede toplumsal ve bireysel refahı sağlama, bireylerin yaşam standartlarını yükseltme konularında önemli katkılar sağlamaktadır. Günümüz dünyasında girişimciliğin önemi bunlarla da sınırlı olmayıp, özellikle iş kurma yoluyla ekonomik büyüme, kaliteyi artırma, teknolojik ilerleme ve sosyal uyum gibi birçok nedenden ötürü uluslararası alanda son derece önemli görülmektedir (Aparicio, Audretsch \& Urbano 2016).

Girişimcilik bir kültür meselesi ve bir zihin meselesidir. Bu durum girişimcilik eğitiminin ülkeler, toplumlar, firmalar, dernekler vb. içerisinde girişimci bir kültür yaratmaya ve / veya bireylerin zihniyetini değiştirmeye yardımcı olduğu anlamına gelmektedir. Kültürel ve zihinsel duruma, esas olarak değerler, inançlar ve tutumlar açısından yaklaşılmaktadır (Fayolle \& Klandt, 2006). Bunun dişında bir kişinin başarılı bir girişimci olmasında etkili olan faktörleri belirlemeye yönelik olarak çok sayıda çalışma yapılmıştır. $\mathrm{Bu}$ çalışmalar, girişimciliğin basit terimlerle açıklanamayacağını açıkça göstermiştir. Mevcut literatürde ilk olarak bireylerin kendi işlerini kurma sebeplerini açıklamaya yönelik çabalarının çoğu iki genel tipte incelenmiştir. Bunlar; psikolojik açıklamalar ve çevre faktörünün itici gücü ile ilgili açıklamalardır. Psikolojik alanda yapılmış olan McClelland'ın (1961, 1965) "başarı yaklaşımı" olarak bilinen; bazı özelliklere sahip bireylerin girișimcilerin yaşamlarını karakterize eden zorluk ve ödül türlerini arama eğilimini vurguladığı teorisi bilinen en iyi örnektir (akt. Brockhaus, 1975). Literatüre bakıldığında girişimci bireylerin özellikleri arasında bilişsel uyanıklık, özerklik, öz yeterlik, başarma ihtiyacı, firsat keşfi ve kullanımı, risk alma eğilim, proaktiflik, yenilikçilik, kontrol odağı bulunmaktadır.

\section{Bilişsel Uyanıklık}

Girişimciliğin birçok metaforu vardır ve birçok paradoks içerir. Bu süreç içerisinde her tür engeli, durumu lehine çevirmek girişimciler için bir zorluktur (Timmons, Spinelli \& Tan, 2016) fakat belirgin özelliklerinden biri olan bilişsel uyanıklık bu konuda onlara yardımcı olmaktadır. Yapılan araştırmalara göre; bu kişiler özel bir çaba sarf etmeden etrafındaki gelişmeleri, farklılıkları, firsatları, tehlikeleri fark edebilmektedirler Sahip oldukları bu zihinsel süreçler sayesinde dikkatlerini doğrudan yönlendirerek yürütmek istedikleri herhangi bir olay için ya da gerçekleştirmeyi düşündükleri hedefleri için bilgi işleme ve akıl yürütme yetilerini aktif bir şekilde kullanabilmektedirler (Gaglio \& Katz, 2001; Hisric vd., 2016).

\section{Fırsat Keşfi ve Kullanımı}

Bir keşif süreci olarak girişimcilik bilinmeyenle ilgilenmeyi içermektedir. Bir girişimci için firsat keşfetme olasılığı, araştırılacak alanın dışsal olarak verildiği, gerçek olduğu, ancak henüz ortaya çıkmadığı anlamına gelmektedir. Bir arz ve/veya talep açısından eksik bir resimle karşılaşan girişimci, yeni bir girişim yaratmak için bu firsatların neler 
olduğunu keşfetmeye çalışmaktadır (Miller, 2007). Girişimcilikte fırsat keşfi ve kullanımı gelişimin fırsat yönüne odaklanmaktadır. Fikir kaynaklarının araştırılması, kavramların geliştirilmesi ve girişim firsatlarının uygulanması yaratıcı yollarla ele alınmaktadır (Frederick, O’Connor \& Kuratko, 2016). Üstün firsatlarda karar verilmiş kalıplar vardır ve bu kalıpları tanımak girişimci bir beceridir (Timmons vd., 2016). Ayrıca, bu düşünceye göre; doğru eylem için doğru fikri doğru zamanda geliştirmek, (Frederick vd., 2016) sürekli devam etmek, gelişmek için sürekli olarak mevcut yeterliliklerin ötesindeki yeni firsatları tanımlamak girişimci için ve organizasyonlar için başarının anahtarıdır (Shepherd \& DeTienne 2001).

\section{Başarma İhtiyacı}

Başarma ihtiyacı teorisi, yüksek başarı ihtiyacı hisseden insanların çeşitli şekillerde ayırt edici olduğunu belirterek bu faktörlerin neler olduğunu tanımlamaktadır (Naji, 2019). McClelland (1961) başarı motivasyonu yüksek olan bireylerin, sonuçlar üzerinde daha fazla kontrole izin veren, performans konusunda doğrudan ve acil geri bildirim sağlayan ve orta düzeyde risk sunan mesleklere devam etmelerinin daha muhtemel olduğunu savunmaktadır. Bu kişiler aldıkları riskler aracılığıyla daha fazla çaba göstermek için motive olurlar. Girişimcilik bu özellikleri karşılayacak en muhtemel iş ortamlarıdır. Başka bir deyişle; kişi yüksek başarma ihtiyacı sayesinde daha fazla çalışacak ve bu sayede hedeflediklerine ulaşacaktır (akt. McClelland, 1965).

\section{Risk Alma Ĕğilimi}

Girişimcilik ve yönetim araştırmalarında olduğu gibi ekonomi ve karar teorisinin yanı sıra girişimcilik ve risk alma yakından ilişkili kavramlardır (Bhole, 2007; Campbell, 1992; Hisrich vd., 2016). Birçok araştırmada, risk yönetiminde kontrol sistemlerinin önemli bir rol oynadığına dair bir varsayım vardır (Collier vd.,2007). Risk değerlendirildikten sonra karar vermek girişimci davranışların merkezinde yer almaktadır (Dayal, 2007). Bu durum girişimcilerin genellikle belirsizlikle yüzleşmesi; öngörü ve kontrol işlevlerini üstlenerek kararlar almak zorunda olduğu, girişimcinin vizyon sahibi olduğu ve bilgi yönetim becerisine sahip olduğu anlamına gelmektedir (Bhole, 2007). Öyle ki; girişimcilik yapılandırılmamış ve benzersiz konuları ele alırken işlevsel sorunlar daha yapılandırılmış ve tekrarlayıcıdır. Girişimciliğin formülasyonu ve uygulanması, fonksiyonel disiplinlerdeki bu süreçlerden daha fazla belirsizlikle karşı karşıyadır (Shepherd \& Douglas, 1998).

\section{Yenilikçilik-İnovasyon}

21. yüzy1l, inovasyonun her tür ve büyüklükteki organizasyonda rekabet avantajı ve başarıya giden yol olarak kabul edildiği bir dönemdir (Kuratko, 2015). Girişimcilik, yeni hizmetlerin yanı sıra ürünlerde de yenilikler yapmak için kilit başarı faktörlerinden biridir (Morishita, 2019). Girişimcilik kavramının yenilikçilik çerçevesinden değerlendirilmesi ilk olarak Joseph Schumpeter tarafindan popüler hale getirilmiştir. Schumpeter'ın girişimcilik ile ilgili "önceden var olmayan ürünlerin yeni çeşitlerinin üretilmesi” olarak yaptığı tanımlamasında girişimciliğin yenilikçi rolünü vurguladığı görülmektedir. Bu durumda girişimci olan kişi; yeni kombinasyonları başlatarak eski olanı piyasadan elimine ederek yenilikçiliğin en temel özelliği olduğunu kanıtlamış olur (Hall \& Sobel, 2006).
İşletme perspektifinden bakıldığında girişimcilik; inovasyonu vurgulayan, firsatları kaybetmeden rakipleri devralmak için agresif bir eylemde bulunan ve beklenmedik bir durumda sorunlar olduğunda çözümler sunan organizasyonel bir süreçtir (Kim \& Lee, 2018). Aynı zamanda kurumsal girişimciliğin arkasındaki en büyük itici güç; yenilik, yaratıcılık ve liderliğin yeniden canlandirılmasıdır (Kuratko, 2015).

\section{Proaktiflik ve İnisiyatif Alma}

Proaktiflik; gelecekteki talep beklentisiyle hareket etme, firsatlar için bir arayış ve çevreyi şekillendirme öngörüsü olan bir lider için ileriye dönük bir bakış açısıyla yeni ürünlerin ortaya konulması, etkisini yitiren uygulamaların dönüştürülmesi ya da ortadan kaldırılması olarak tanımlanmaktadır (Mihi-Ramirez vd., 2015; Venkatraman, 1989). Artan rekabet ile birlikte yapılan insiyatifi yansıtmakla birlikte risk alma, rekabet agresifliği ve cesareti içermektedir (Antonic \& Hisrich, 2001). Değişimin öncüleri olarak bilinen proaktif bireyler, gerçekleşen değişimlerde inisiyatif alabilen, firsatları takip eden, yakaladığı firsatlar konusunda hemen eyleme geçebilen kişilerdir (Bateman \& Crant, 1993). İnsiyatif almanın da ötesinde yaşadıklarının sorumluluğunu alan ve davranışlarının koşulların değil kendi kararlarının bir işlevi olduğuna inanan bireyler olarak ifade edilmektedir (Covey, 1989).

\section{Öz Yeterlik}

Bandura'nun Öz Yeterlik Teorisi kişisel kontrol hakkındaki inançlarla ilgili felsefe ve psikoloji alanında uzun bir geçmişe sahiptir. İnsan davranışı ve psikolojik iyi olma arasındaki ilişkiyi araştırmaya çalışan birçok teoriyle birlikte Bandura (1977)'nın algılanan yetkinlik kavramı “özyeterlik" olarak tanımlandı ve insan davranışını nasıl geliştirdiği ve etkilediği teorisinde yer aldı. Buna göre; insanlar ne yapacaklarını tam olarak bilmelerine rağmen çoğu zaman en uygun şekilde davranamazlar; bunun sebebi kendini yönlendiren düşüncenin, aynı zamanda bilgi ve eylem arasındaki ilişkiye aracılık etmesidir. $\mathrm{Bu}$ durum insanların yeteneklerini nasıl değerlendirdikleri ve kendi etkililik algıları yoluyla motivasyonlarını ve davranışlarını nasıl etkilediği ile ilgilidir (akt. Bandura, 1982).

\section{Özerklik}

Girişimciliğin özerklik boyutu ise, bu anlayışın bir gereği olarak, kendini tanımanın, kişisel hayallerinin ve amaçlarının ne olduğunu bilmenin ve bu amaçlara göre hareket etmenin kararlılığına sahip olmanın ötesine uzanmaktadır (Gelderen, 2010). Bunun yanı sıra genellikle bir vizyon yaratmayı, sürdürmeyi ve sonuçlandırmayı amaçlayan kişi veya ekip tarafindan gerçekleştirilen eylemler olarak tanımlanmaktadır (Lumpkin \& Dess, 1996). Özerk bireylerin kendi oluşturdukları işten sorumlu olmaları bireylere büyük özgürlük alanı sağlamakta, sahip oldukları bu özgürlükle birlikte küresele açılıp, rekabet edebilmelerini ve imaj yaratmalarını kolaylaşmaktadır. Çünkü davranışlar, insanların gerçek bir irade ve seçim duygusu ile hareket ettikleri ölçüde özerktir (Williams, Rodin, Ryan, Grolnick \& Deci, 1998). Bu durum özerklik deneyiminin bireysel koşullardan ve girişimcinin eylemlerinden de etkilendiği gerçeğini gözler önüne sermektedir (Gelderen, 2016). Aynı zamanda özerk bireyler, bir topluluğun üyeleri olarak 
ilgilenmek zorunda oldukları kültürel ve toplumsal talep ve beklentilerin farkındadırlar (Chirkov, 2014). İnsanlar bir durumda veya belirli bir davranış için özerk bir şekilde motive olduklarında, tipik olarak temel psikolojik ihtiyaçların her birinde de tatmin olacaklarını hissederler; çünkü otonom motivasyon özerklik ihtiyacının doğrudan tatminini sağlar ve insanlara kendileri ile ilgili ve yeterlilik ihtiyaçlarını karşılamada psikolojik özgürlük sağlar (Deci \& Ryan, 2014).

\section{Kontrol Odağı}

Kontrol odağı kavramını 1950'lerde Rotter (1954) ortaya koymuştur. Bireyin yaşam olaylarını kontrol etme yeteneklerine olan inancinı ifade etmektedir (akt.Strauser, 2002). Rotter (1966)'a göre kontrol odağ 1 kavramının kişinin kendi üzerinde oluşturduğu kontrol duygusunu gösteren nitelikleri mevcuttur. D1ş ve iç kontrol odağ 1 olmak üzere iki farklı şekilde karşımıza çıkmaktadır (akt. Graffeo \& Silvestri, 2006). İçsel kontrol odağına sahip olan bireyler yaşadıkları her durumun sorumluluğunu almaktadırlar; bu durum kişi üzerinde iç etmenlerden gelen kontrolün hakim olduğu anlamına gelmektedir. Bireyin dış kontrol odaklı olması ise; kişinin dış etmenler tarafından kontrol edildiği anlamına gelir ve bu bireyler, olayların başkalarından ya da diş koşullardan hatta şans faktöründen etkilendiğine inanmaktadırlar (Flammer, 2001) Knoop (1981)'a göre iç kontrol odaklı bireyler daha kolay motive olduklarından ya da kendi kendilerini motive ettiklerinden yönetilmeye ihtiyaç duymazlar (akt. Lumpkin \& Dess, 2001). Başka bir ifadeyle iç kontrol odaklı bireyler başarılı olmak için dış güçler olmaksızın kendi motivasyonları ile girişimci bir arayışa yönelmektedirler (Frederick vd., 2016; Silvester vd., 2002). Bu sebeple, iç kontrol odaklı bireyler amaçlarına ulaşmak için ya da başarılı olmak için daha fazla çaba harcarlar (Lüthje \& Franke, 2003). Bandura'nın öz yeterlik teorisi kişinin kontrol odağına atıfta bulunarak başarı ve başarısızlık durumunun kişinin bu süreci kontrol etmesiyle ilgili bir durum olduğuna değinmektedir (Bandura, 1982).

\section{Girişimcilik ile Kontrol Odağı İlişkisi}

Bireylerin genel olarak içsel ödüller yoluyla kendi fikirlerini geliştirmeleri, kaderlerini daha iyi kontrol etmeleri, dahil oldukları projelerin başarısı için nihai sorumluluğa sahip olmaları ve bunun sonucunda memnuniyet duygusunu yaşamaları mümkün olmaktadır (Kuratko vd., 2005). Mantıksal olarak iç kontrol odağı, kişinin olayları kontrol edebileceği inancı ile güç elde etmesi konusunda bir motivasyon kaynağı olarak düşünülebilmektedir (Borland, 1975). Daha fazla özgüvenli ve bağımsız olma eğiliminde olan psikolojik özellikleri doğal olarak onları başarılı girişimcilik için daha uygun hale getirmektedir (Pandey, 1979). Bu tip girişimciler, kendi özgün ve yenilikçi görüşleri doğrultusunda rekabetçi bir örgüt kültürü yaratmak isterler (Zhang \& Bruning, 2011) ve süreç boyunca yaşayacakları muhtemel olan her tür stresli durumu kişisel olarak kontrol edebilme olasılıkları daha yüksektir. Bu durum, sorunlarla başa çıkma çabalarının artarak problemleri rahatlıkla çözebildikleri gerçeği ile örtüşmektir (Peacock \& Wong, 1996). Bu noktada iç kontrol odağının, bir mevki sahibi olma ile tutarlı olduğu ve hedeflere ulaşma yollarının başarı motivasyonu ile yönlendirildiği söylenebilir.
Literatürde geçen kontrol faktörleri girişimci bireylerin sahip olması gereken özelliklerle örtüşmektedir. Kontrol faktörleri şunlardır:

(a) Beceri: Girişimcilerin işleri daha değerli hale getirme ve gereken kapasiteye sahip olma becerisidir.

(b)Yetenek: Girişimcilerin öğrenme ve deneyim sürecinde edindikleri işleri yapma yetenekleridir.

(c) Çaba: Girişimcilerin hedeflere ulaşmak için gösterdiği emektir; çünkü başarılı girişimciler, başarının sıkı çalışarak elde edileceğini düşünürler (Hansemark, 2003; Göksel ve Aydıntan, 2011'den aktaran: Kusumawijaya, 2019).

\section{Yöntem}

Bu bölümde, araştırma modelinden, evren-örneklemden, ölçek geliştirme sürecinden, verilerin toplanmasından ve verilerin analizinden bahsedilmektedir.

\subsection{Araştırma Modeli}

$\mathrm{Bu}$ araştırma, akademisyenlerin iç kontrol odaklı girişimcilik eğilimlerini belirlemek amacıyla yapılan bir ölçek geliştirme çalışmasıdır. Ölçek geliştirme sürecinde, bir durumu olduğu şekilde ortaya koymayı amaçlayan (Karasar, 2012), sosyal bilimlerde yaygın olarak kullanılan ve büyük gruplar üzerinde çalışma imkanı veren (Büyüköztürk, 2014) nicel araştırma yöntemlerinden tarama modeli çeşitlerinden genel tarama deseni kullanılmıştır.

\subsection{Araştırmanın Evreni ve Örneklemi}

Araştırmanın evrenini Türkiye genelindeki üniversitelerde görev yapmakta olan akademisyenler oluşturmaktadır. Araştırmanın örneklemi seçkisiz örnekleme yöntemlerinden basit seçkisiz örnekleme yöntemi ile belirlenmiştir. Seçkisiz örnekleme yöntemleri, örnekleme seçilme olasılıkları eşit ve bağımsız olması sebebiyle örneklemin evreni temsil etme gücünün yüksek olduğu bir yöntemdir (Büyüköztürk et al., 2008). Öncelikle Türkiye genelindeki devlet üniversiteleri ve özel üniversiteler listelenmiştir ve istenilen örneklem sayısına ulaşılana kadar kişi seçilerek örnekleme dahil edilmiştir. $\mathrm{Bu}$ örnekleme yöntemiyle seçilen Türkiye genelindeki üniversitelerde 2019-2020 eğitim öğretim yılında görev yapmakta olan her kademeden 571 akademisyen araştırmanın örneklemini oluşturmaktadır.

Araştırmaya katılan akademisyenin demografik özellikleri Tablo 1'de gösterilmiştir. 
Tablo 1. Akademisyenlerin Demografik Verilerine İlişkin Dağılımları

\begin{tabular}{llrr}
\hline Değişken & Gruplar & f & \% \\
\hline \multirow{2}{*}{ Cinsiyet } & Kadın & 276 & 48,3 \\
& Erkek & 295 & 51,7 \\
\hline & Arş. Gör. & 180 & 31,5 \\
& Öğr. Gör. & 64 & 11,2 \\
\multirow{2}{*}{ Unvan } & Dr. & 75 & 13,1 \\
& Dr. Öğr. Üyesi & 156 & 27,3 \\
& Doç. & 80 & 14 \\
& Prof. & 16 & 2,8 \\
\hline \multirow{2}{*}{ Mezuniyet } & Lisans & 6 & 1 \\
durumu & Y. Lisans & 135 & 23,6 \\
& Doktora & 430 & 75,3 \\
\hline \multirow{4}{*}{ Hizmet Y1lı } & 0-5 y1l & 78 & 13,7 \\
& 6-10 y1l & 188 & 32,9 \\
& 11-15 y1l & 93 & 16,3 \\
& 16-20 y1 & 115 & 20,1 \\
& 21 y1l ve üstü & 97 & 17 \\
\hline \multirow{2}{*}{ İdari Görev } & Var & 122 & 21,4 \\
& Yok & 449 & 78,6 \\
\hline Girişimcilik ile & Var & 219 & 38,4 \\
ilgili çalışma & Yok & 352 & 61,6 \\
\hline
\end{tabular}

Tablo 1'de görüldüğü gibi araştırmaya katılan akademisyenler cinsiyete göre $295^{\prime} \mathrm{i}(\% 51,7)$ erkek, 276's1 $(\% 48,3)$ kadın olarak dağılmaktadır. Unvana göre 180'i $(\% 31,5)$ arş. gör., 64'ü $(\% 11,2)$ öğr. gör., 75'i $(\% 13,1)$ dr., 156 's1 (\%27,3) dr. öğr. üyesi, 80’i (\%14) doç. dr., 16’sı $(\% 2,8)$ prof. dr. olarak dağılmaktadır. Akademisyenler eğitim durumuna göre 430'u (\%75,3) doktora, 135'i $(\% 23,6)$ yüksek lisans, 6'sı (\%1) lisans olarak dağılmaktadır. Akademisyenlerin hizmet yılına göre 78'i $(\% 13,7)$ 0-5 yıl, 188'i (\%32,9) 6-10 y1l, 93'ü (\%16,3) 11-15 y1l, 115'i (\%20,1) 16-20 y1l, 97'si (\%17) 21 y1l ve üstü olarak dağılmaktadır. Akademisyenler arasından $122 \quad(\% 21,4)$ kişinin idari görevi var, $449(\% 78,6)$ kişinin idari görevi yoktur. Akademisyenlerin 219'unun $(\% 38,4)$ girişimcilikle ilgili çalışmaları varken; 352'sinin $(\% 61,6)$ girişimcilikle ilgili çalışması yoktur.

\section{3. İç Kontrol Odaklı Girişimcilik Eğilimi Ölçeği Geliştirilme Süreci}

Ölçek geliştirme sürecinde takip edilmesi gereken bazı basamaklar vardır. İlk basamakta madde havuzunun oluşturulması sonrasında sırasıyla; uzman görüşüne sunulması bu görüşler doğrultusunda pilot uygulamanın yapılması ve elde edilen verilerle geçerlik güvenirlik çalışmasının yapılması bulunmaktadır (Özdamar, 2017). İç kontrol odaklı girişimcilik ölçeğinin geliştirme sürecinde Özdamar (2017)'ın belirttiği adımlar takip edilmiştir. ilk olarak literatür taraması yapılarak daha önce yapılan araştırmalar incelenmiş, detaylı bir inceleme yapıldıktan sonra akademisyenlerin iç kontrol odaklı girişimcilik eğilimlerini ölçmek için ilk etapta 50 maddelik bir soru havuzu hazırlanmıştır. Oluşturulan madde havuzu Anderson (1977), Antoncic ve Hisrich (2001), Bandura (1982), Bandura (2002), Bateman ve Crant (1993), Bernardi (2001), Carland vd, (1984), Collins, Hanges (2004), Deci ve Ryan (1980), Demirkan (2006), Drucker (1985), Ducette ve Hassan vd., (2016), Gaglio (1997), Hall ve Sobel (2006), Hermawan vd. (2016), Hisrich vd, (2016), Jain (2011), Kirzner (1979), Koh, (1996), Kuratko and Hodgets (2001), Lefcourt (1984), Lefcourt., et all (1985), Loosemore ve Lam (2004), Lumpkin \& Dess (1996), Lumpkin ve Dess (2001), Lüthje ve Franke (2003), McClelland (1965), McDougall (1989), Mill (1848), Oliver vd (2006), Prakash vd (2015),
Rotter (1966), Rotter (1975), Sanchez vd, (2011), Schumpeter (1947), Silvester vd., (2002), Strauser vd (2002), Tuten ve Neidermeyer (2004), Venkatraman (1989), Yukl and Latham (1978), Zhang and Bruning, (2011), Williams ve Stack (1972), Wolk (1973) tarafından yapılan çalışmalar doğrultusunda hazırlanmıştır. İkinci kez yapılan literatür taraması sonrasında oluşturulan madde havuzundaki aynı anlama gelen ifadeler eğitim bilimleri alanında uzman olan 2 profesör doktor, 1 doçent doktor unvanlı öğretim üyesinin görüşleri doğrultusunda elenerek 37 madde haline getirilmiştir. Sadeleştirilmiş madde havuzu; ölçekte yer alan maddelerin, ölçülmek istenen davranışı belirleme konusunda her yönüyle yeterliliğini ve niteliğini ortaya koymak amacıyla yapılan kapsam geçerliğinin (Büyüköztürk, 2006) sağlanması amacıyla alanda uzman olan 10 kişinin görüşlerine sunulmuştur. Uzmanların görüşlerini ifade edebilmeleri için; 3'lü likert tipinde uzman değerlendirme formu oluşturulmuştur. Maddelerin kapsam geçerliği analizinde Lawshe tekniğinden yararlanılmıştır. Bu teknik, maddelerin ölçekte bulunma durumuna ilişkin bir madde istatistiğidir (Lawshe, 1975). Buna göre; uzmanlardan gelen dönütler sonucunda 37 maddenin her birine ait madde kapsam geçerlik indeksi hesaplanmıştır. Kapsam geçerlik indeksi $(\mathrm{KGO}=(\mathrm{NG} / \mathrm{N} / 2)-1)$ formülünde belirtildiği gibi herhangi bir maddeye ilişkin "gerekli” görüşünü belirten uzman sayısının (NG), toplam uzman sayısına (N) bölünmesiyle elde edilmektedir. Lawshe (1975)'a göre uzman sayısına göre ölçeğe alınacak maddelerin sahip olması gereken minimum KGO değerleri Tablo 2'de belirtilmektedir.

Tablo 2. KGO'lar için minimum değerler

\begin{tabular}{cc}
\hline Uzman sayısı & Minimum Değer \\
\hline 7 & 0,99 \\
8 & 0,75 \\
9 & 0.78 \\
10 & 0,62 \\
\hline
\end{tabular}

Ölçeğe alınacak maddelerin kabul edilebilir KGİ değerinin 10 kişilik uzman sayısı için belirtilen KGO minimum değeri olan 0,62'nin üstünde olması önerilmektedir. Lawshe (1975) tekniğinde 0.05 anlamlılık düzeyinde olan 10 uzman için belirlenen kapsam geçerlik indeksi (KGI) 0,75 olarak belirlenmiştir ve belirlenen ölçütü $(0,75>0,62)$ sağladığı görülmüş̧ür. Uzman dönütleri ve analiz değerleri göz önüne alınarak soruların ifade ediliş şekillerinde düzenlemeler yapılmış, çıkarılması gereken madde olmadı̆̆ı uzmanlar tarafından belirlenmiş ve madde sayısı 37 olarak belirlenmiştir. Oluşturulan ölçek formu maddelerle ilgili ifadelerin anlaşılma konusunda netlik sağlaması amacıyla 50 akademisyene uygulanarak pilot uygulama aşaması gerçekleştirilmiştir. Pilot uygulama sonrasında maddelerin doğru olarak anlaşıldığı görüldüğü için maddelerde herhangi bir değişiklik yapılmamıştır. Daha sonra oluşturulan ölçek formunun geçerlik güvenirlik analizleri yapılmıştır. Geçerlik güvenirlik çalışması sürecinde öncelikle yapı geçerliliğini sınamak için açımlayıcı ve doğrulayıcı faktör analizleri daha sonra ölçeğin ayırt ediciliğini tespit etmek için ayırt edicilik analizi yapılmıştır. Ölçülmek istenen yapının iç tutarlılığını tespit edebilmek için Cronbach Alpha katsayı değerleri dikkate alınmıştır. 


\subsection{Verilerin Toplanmas1}

Araştırmaya etik kurul izni alındıktan sonra başlanmıştır. Araştırmada kişisel veri toplanacağından 6698 sayılı Kişisel Verilerin Korunması Kanunu ve ilgili mevzuat uyarınca kişisel verileri korumak amacıyla gerekli tüm tedbirler alınmış olup, gerekli her türlü yükümlülük özenle yerine getirilmiştir. Sabahattin Zaim Üniversitesi Lisansüstü Eğitim Enstitüsü Eik Kurulu tarafindan belirtilen etik kurul kararı evrak tarih ve sayıs1: 10/07/2020-E.3283 25.06.2020 tarihli ve 2020/06 sayılı etik kurulu kararıdır.

Ölçeğin verileri 2019-2020 y1lında Türkiye genelindeki devlet üniversitelerindeki ve özel üniversitelerdeki her kademe akademisyene seçkisiz örnekleme yöntemlerinden kolay ulaşılabilir ve random örnekleme yöntemi ile ulaşılan 571 kişiden elde edilmiştir. Verilerin toplanması zamansal ve mekansal engelleri ortadan kaldırması nedeniyle online formlar üzerinden hazırlanan anket formu (Şimşek, Veiga ve Lubatgin,2005:180) aracılığıyla mail yoluyla toplanmıştır. Kline (1994), güvenilir faktörler çıkartmak için 200 kişilik örneklemin genellikle yeterli olacağını, ancak daha iyi sonuçlar için daha büyük örneklemle çalışmanın yararlı olacağını vurgulamaktadır (akt. Büyüköztürk, 2002). Bu sebeple açımlayıcı faktör analizi için 291 kişiye ölçek uygulanmıştır. Kline (2005)'a göre, doğrulayıcı faktör analizi için örneklem sayısının madde sayısının 10 katı olması gerektiği (akt., Çapık, 2014) bilgisine dayanarak AFA sonrasında düzeltmelerin yapıldığı ölçme aracı doğrulayıcı faktör analizi için 280 akademisyene uygulanmıştır.

\subsection{Verilerin Analizi}

Araştırma kapsamında elde edilen veriler SPSS programında gerekli düzenlemeler yapılarak analiz edilmiştir. Ölçek geliştirme aşamaları takip edilerek açımlayıcı ve doğrulayıcı faktör analizleri ile birlikte güvenirlik analizleri de yapılmıştır. Açımlayıcı faktör analizi öncesi faktör analizinin uygulanabilirliğine yönelik ön varsayım testleri KMO (Kaiser-Meyer-Olkin) ve Barlett testleri uygulanmıştır. Faktör analizi uygulamasında varimax dik döndürme yöntemi kullanılarak verilere temel bileşenler analizi uygulanmıştır. Ölçeğe ait faktör sayısının belirlenmesinde yamaç birikinti grafiği incelenmiştir. Güvenirliğinin sağlanmasında; Cronbach Alpha güvenirlik katsayısı değerleri dikkate alınmıştır.

\section{Bulgular}

Tablo 3. İç Kontrol Odaklı Girişimcilik Ölçeği Madde Analizi

\begin{tabular}{|c|c|c|c|c|}
\hline & 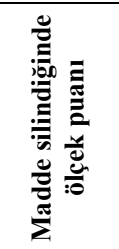 & 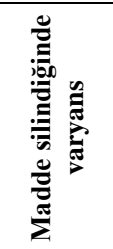 & 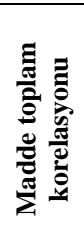 & 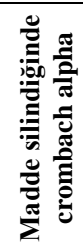 \\
\hline $\begin{array}{l}\text { 1. Yeni bir şey } \\
\text { öğrenirken güçlü } \\
\text { yönlerimden } \\
\text { faydalanırım }\end{array}$ & 135,526 & 195,464 & ,365 & ,907 \\
\hline $\begin{array}{l}\text { 2. Olumsuz durumları } \\
\text { lehime çevirebilecek } \\
\text { taktikler kullanırım }\end{array}$ & 136,351 & 191,042 & ,446 & ,906 \\
\hline $\begin{array}{l}\text { 4. Hatalarımın olduğu } \\
\text { durumlarda yeni bir } \\
\text { strateji belirleyebilirim }\end{array}$ & 136,058 & 194,552 & ,410 & ,907 \\
\hline $\begin{array}{l}\text { 5. Hedeflerime } \\
\text { ulaşmak için planlama } \\
\text { sürecini kontrol } \\
\text { edebilirim }\end{array}$ & 136,007 & 193,876 & ,385 & ,907 \\
\hline $\begin{array}{l}\text { 6. Yaptığım planlara } \\
\text { uygun bir şekilde } \\
\text { ilerleyebilirim }\end{array}$ & 136,282 & 193,920 & ,347 & ,908 \\
\hline $\begin{array}{l}\text { 7. Hedeflerime } \\
\text { ulaşmak için engelleri } \\
\text { kontrolümde tutmaya } \\
\text { calıșırım }\end{array}$ & 136,234 & 191,704 & ,467 & ,906 \\
\hline $\begin{array}{l}\text { 8. Hedeflerime } \\
\text { ulaşmak için kendimi } \\
\text { motive edebilirim }\end{array}$ & 136,010 & 190,141 &, 526 & ,905 \\
\hline $\begin{array}{l}\text { 9. Bir konuda elde } \\
\text { ettiğim başarı üzerinde } \\
\text { kendi çabamın etkili } \\
\text { olduğunu bilirim }\end{array}$ & 135,794 & 194,737 &, 361 & ,907 \\
\hline $\begin{array}{l}\text { 10. Zor hedefler beni } \\
\text { yıldırmaz }\end{array}$ & 136,189 & 190,043 & ,485 & ,906 \\
\hline $\begin{array}{l}\text { 11. Zayıf yönlerimi } \\
\text { geliştirmeye çalışırım }\end{array}$ & 136,007 & 191,428 &, 516 & ,905 \\
\hline $\begin{array}{l}\text { 13. Bir konuda } \\
\text { alacağım riskin } \\
\text { sonuçlarını } \\
\text { üstlenebilirim }\end{array}$ & 135,677 & 193,440 &, 431 & ,906 \\
\hline $\begin{array}{l}\text { 14. Yüksek getiri } \\
\text { sağlayabilecek bir } \\
\text { durum için özveride } \\
\text { bulunabilirim }\end{array}$ & 136,113 & 194,522 & ,328 & ,908 \\
\hline $\begin{array}{l}\text { 15. Karşılaştı̆̆ım risk } \\
\text { durumlarını kontrol } \\
\text { edebilirim }\end{array}$ & 136,247 & 192,518 &, 548 & ,905 \\
\hline $\begin{array}{l}\text { 16. Risk alarak } \\
\text { mesleğimde } \\
\text { ilerleyebileceğimi } \\
\text { düsünürüm }\end{array}$ & 136,670 & 189,567 & ,440 & ,906 \\
\hline $\begin{array}{l}\text { 17. Yenilikleri } \\
\text { mesleğimde ne şekilde } \\
\text { kullanabileceğimi } \\
\text { bilirim }\end{array}$ & 135,986 & 191,538 &, 592 & ,905 \\
\hline $\begin{array}{l}\text { 18. Özgün bir ürün } \\
\text { ortaya koyma } \\
\text { konusunda kendimi } \\
\text { yeterli görüyorum }\end{array}$ & 136,186 & 188,710 & ,556 & ,905 \\
\hline $\begin{array}{l}\text { 19. Çalışmalarımda } \\
\text { yeni yöntemler } \\
\text { denerim }\end{array}$ & 136,216 & 188,625 & ,633 & ,904 \\
\hline $\begin{array}{l}\text { 20. Yenilikçi projeleri } \\
\text { uygulamaya koymak } \\
\text { için firsatlar yaratırım }\end{array}$ & 136,474 & 186,457 & ,624 & ,904 \\
\hline $\begin{array}{l}\text { 21. Çalışmaları daha } \\
\text { işlevsel hale getirmek } \\
\text { için yeni fikirler } \\
\text { üretebilirim }\end{array}$ & 136,069 & 191,078 & ,579 & ,905 \\
\hline $\begin{array}{l}\text { 22. Genellikle özgün } \\
\text { konular üzerinde } \\
\text { çalıșmayı tercih ederim }\end{array}$ & 135,924 & 191,987 & ,506 & ,906 \\
\hline
\end{tabular}




\begin{tabular}{|c|c|c|c|c|}
\hline & 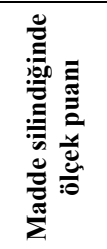 & 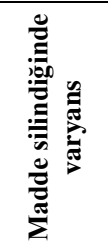 & 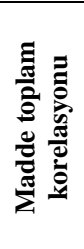 & 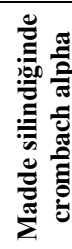 \\
\hline $\begin{array}{l}\text { 26. Ortaya çıkan } \\
\text { krizleri firsata } \\
\text { cevirebilirim }\end{array}$ & 136,876 & 191,619 & ,421 & ,907 \\
\hline $\begin{array}{l}\text { 27. Bir projede } \\
\text { yönlendiren ve veya } \\
\text { harekete geçiren taraf } \\
\text { ben olurum }\end{array}$ & 136,536 & 188,063 &, 584 & ,904 \\
\hline $\begin{array}{l}\text { 29. Amaçladı̆̆ım bir } \\
\text { şeyi gerçekleştirmek } \\
\text { için başkalarının } \\
\text { desteğine ihtiyaç } \\
\text { duymam }\end{array}$ & 136,808 & 192,246 &, 350 & ,908 \\
\hline $\begin{array}{l}\text { 30. Yaptı̆̆ım her } \\
\text { eylemde, aldı̆̆ım her } \\
\text { kararda kontrol bana } \\
\text { aittir }\end{array}$ & 136,316 & 191,300 & ,467 & ,906 \\
\hline $\begin{array}{l}\text { 31. Yapabileceklerim } \\
\text { doğrultusunda hedefler } \\
\text { belirlerim }\end{array}$ & 135,883 & 193,566 & ,496 & ,906 \\
\hline $\begin{array}{l}\text { 32. Tek başıma özgün } \\
\text { bir çalışma } \\
\text { yürütebilirim }\end{array}$ & 135,986 & 191,000 & ,461 & ,906 \\
\hline $\begin{array}{l}\text { 37. Bir konuda başarı } \\
\text { elde ettiğimde } \\
\text { kendimle gurur } \\
\text { duyarım }\end{array}$ & 135,759 & 194,183 & ,325 & ,908 \\
\hline
\end{tabular}

Katılımcıların maddelerin ifade ettiği önermeleri doğru anladıkları ve maddelere tarafsız bir şekilde yanıt verdiklerini tespit edebilmek için; verilen yanıtların maddeler arasında ve ölçek toplamı ile pozitif korelasyona sahip olması gerekmektedir. Ölçekteki bir maddenin, maddeler toplamı ile korelasyon katsayısının 0,30 ve üzeri olması ayırt ediciliğinin yüksek olduğunu göstermektedir (Büyüköztürk, 2011; Tavşancıl, 2018). Bir değişkenin 0.30'luk faktör yükü, faktör tarafindan açıklanan varyansın $\% 9$ olduğunu göstermektedir. $\mathrm{Bu}$ düzeydeki varyans işaretine bakılmaksızın 0,60 ve üstü yük değeri yüksek; 0,30-0,59 arası yük değeri orta düzeyde büyüklükler olarak tanımlanabilir ve değişken çıkartma konusunda dikkate alınır (Büyüköztürk, 2002). Tablo incelendiğinde madde toplam korelasyon değerlerinin 0,30 ve üzeri olduğu görülmektedir. Bu sebeple ölçekte 3, 12, 23, 24, $25,28,33,34,35,36$ numaralı maddeler 0,30 altında kaldığından çıkartılmıştır.

\section{İç Kontrol Odaklı Girişimcilik Ölçeğinin Geçerlik Çalışmaları ile İlgili Bulgular}

Ölçeğin yapı geçerliğini sınamak amacıyla açımlayıcı faktör analizi uygulanmıştır. Yapılan Barlett testi sonucunda $(p<0,05)$ faktör analizine alınan değişkenler arasında ilişki olduğu tespit edilmiştir. Yapılan test sonucunda $(\mathrm{KMO}=0.872>0,60)$ örneklem büyüklüğünün faktör analizi uygulamak için yeterli olduğu belirlenmiştir.

Tablo 4. KMO ve Barlett's Testi Değerleri

\begin{tabular}{lll}
\hline $\begin{array}{l}\text { Kaiser-Meyer-Olkin } \\
\text { Örneklem Yeterliliği }\end{array}$ & \multicolumn{1}{c}{, 872} \\
\hline $\begin{array}{l}\text { Barlett's Test of } \\
\text { Sphericity }\end{array}$ & Ki-Kare Değeri & 2701,767 \\
\cline { 2 - 3 } & Sebestlik Değeri & 351 \\
\cline { 2 - 3 } & $\mathrm{p}$ & 0,000 \\
\hline
\end{tabular}

Tablo 4'te görüldüğü gibi; açımlayıcı faktör analizi öncesi faktör analizinin uygulanabilirliğine yönelik ön varsayım testleri KMO (Kaiser-Meyer-Olkin) ve Barlett testleri uygulanmıştır. KMO testi örneklem büyüklügünün faktör analizi uygulanması için yeterli olduğu göstermektedir. Literatürde faktör analizinin uygulanabilmesi için KMO değerinin 0,5'ten yukarı olması gerektiğini belirtilmektedir (Çokluk, Şekercioğlu \& Büyüköztürk, 2018).

Tablo 5. Akademisyenlerin İç Kontrol Odaklı Girişimcilik Ölçeği Bileşenler Matrisi

\begin{tabular}{|c|c|c|c|c|c|c|c|}
\hline \multirow{2}{*}{ Maddeler } & \multicolumn{7}{|c|}{ Faktörler } \\
\hline & 1 & 2 & 3 & 4 & 5 & 6 & 7 \\
\hline İkog 19 & ,711 & & & & & & \\
\hline İkog 20 & 698 & &,- 352 & & & & \\
\hline İkog 17 & 663 & & & & & & \\
\hline İkog 21 & 647 &,- 303 & & & & & \\
\hline İkog 27 & 637 & & & & & &,- 351 \\
\hline İkog 18 & 633 &,- 368 & & & & & \\
\hline İkog 15 &, 596 & & & ,308 & & & \\
\hline İkog 8 &, 584 & ,341 & & & & & \\
\hline İkog 11 &, 575 & & & & &,- 408 & \\
\hline İkog 22 &, 567 &,- 390 & & & & & \\
\hline İkog 31 &, 550 & & & & & & \\
\hline İkog 7 &, 548 & ,382 & & & & & \\
\hline İkog 16 &, 518 & &,- 480 & & & & \\
\hline İkog 32 &, 511 &,- 378 &, 357 & & & & \\
\hline İkog 2 &, 505 & & & & ,393 & &,- 308 \\
\hline İkog 10 & ,497 & & & & &,- 453 & \\
\hline İkog 30 &, 482 & & ,459 & ,422 & & & \\
\hline İkog 26 &, 470 & &,- 323 & & & ,335 &,- 428 \\
\hline İkog 4 & ,460 & & & & & & \\
\hline İkog 13 &, 423 & & & ,382 & &,- 410 & \\
\hline İkog 6 & ,419 & ,645 & & &,- 313 & & \\
\hline İkog 5 & ,464 &, 564 & & & & & \\
\hline İkog 9 & ,392 & & ,559 & &, 343 & & \\
\hline İkog 29 &, 368 &,- 353 & 399 & & & & \\
\hline İkog 37 &, 354 & & & &, 537 & & \\
\hline İkog 1 &, 381 & & & &, 516 & & \\
\hline İkog 14 &, 377 & & & ,388 & & & ,478 \\
\hline
\end{tabular}

Faktör analizinde elde edilen faktörlerin bağımsızlık ve kavramsal anlamlılık şartlarını sağlaması gerekmektedir; fakat bazen çeşitli faktörler aynı değişkene göre yüksek yüklemelere sahipse, faktörleri açıklamak zordur. $\mathrm{Bu}$ sebeple faktör yapısını daha basit ve anlamlı hale getirmek, bu konuda daha iyi yorum yapabilmek için belirli bir açı ile döndürme yapılması gerekmektedir (Özdamar, 1999; Malhotra,2010). Faktör analizi sonucunda bir maddenin birden fazla faktör altında yer alması olası bir durumdur. Gözlenen değişkenlerin sadece bir faktörle yüksek yük değeri verirken, diğer faktörlerde düşük yük değerine sahip olması, faktörü yorumlamayı kolaylaştıracaktır (Büyüköztürk,2002). Bu durum göz önünde bulundurularak birden fazla faktöre girme ile ilgili alınabilecek ölçüt; faktör yükleri arasındaki farkın en az 0,10 olması gerektiğidir (Tavşancıl, 2010'den akt., Bayrakç1,2020:58). Bu doğrultuda; ölçek maddelerinin hangi faktörde yer alacağını tespit etmek ve faktör sayısını belirlemek amacıyla döndürülmüş bileşenler matrisi uygulanmıştır. Varimax dik döndürme yöntemi kullanılarak verilere temel bileşenler analizi uygulanmıştır. Bu uygulama sonucunda özdeğeri 1'in üzerinde olan yedi faktör ortaya çıkmıştır. 
Tablo 6. Akademisyenlerin İç Kontrol Odaklı Girişimcilik Ölçeği Faktör Analizi Sonrası Döndürülmüș Bileșenler Matrisi

\begin{tabular}{|c|c|c|c|c|c|c|c|}
\hline \multirow{2}{*}{ Maddeler } & \multicolumn{7}{|c|}{ Faktörler } \\
\hline & 1 & 2 & 3 & 4 & 5 & 6 & 7 \\
\hline İkog 18 & ,755 & & & & & & \\
\hline İkog 19 & ,746 & & & & & & \\
\hline İkog 21 &, 736 & & & & & & \\
\hline İkog 22 & 670 & & & & & & \\
\hline İkog 20 & 650 & & & & & & \\
\hline İkog 17 &, 561 & & & & & & \\
\hline İkog 6 & &, 856 & & & & & \\
\hline İkog 5 & &, 753 & & & & & \\
\hline İkog 7 & & ,603 & & & & & \\
\hline İkog 8 & &, 502 & & & & & \\
\hline İkog 30 & & &, 744 & & & & \\
\hline İkog 29 & & & ,680 & & & & \\
\hline İkog 32 & & &, 580 & & & & \\
\hline İkog 31 & & & ,460 & & & & \\
\hline İkog 10 & & & & 681 & & & \\
\hline İkog 11 & & & & ,572 & & & \\
\hline İkog 13 & , & & & ,470 & & & \\
\hline İkog 4 & & & & ,470 & & & \\
\hline İkog 14 & & & & & ,772 & & \\
\hline İkog 15 & & & & &, 596 & & \\
\hline İkog 16 & & & & & 567 & & \\
\hline İkog 26 & & & & & &, 797 & \\
\hline İkog 2 & & & & & &, 621 & \\
\hline İkog 27 & & & & & &, 562 & \\
\hline İkog 37 & & & & & & &, 704 \\
\hline İkog 9 & & & & & & & 639 \\
\hline İ́kog 1 & & & & & & & 630 \\
\hline
\end{tabular}

Faktör yük değeri maddelerin faktörle olan ilişkisini gösteren katsayıdır. Faktör yük değerinin 0,45 ve üzeri olması iyi bir seçimdir (Büyüköztürk, 2008:124).Tablo 6'da görüldüğü üzere birinci faktörde toplanan M18, M19, M21, M22, M20, M17 özgünlük olarak; ikinci faktörde toplanan M6, M5, M7, M8 kontrol olarak; üçüncü faktörde toplanan M30, M29, M32, M31özerklik olarak; dördüncü faktörde toplanan M10, M11, M13, M4,başarma ihtiyac1; beşinci faktörde toplanan M14, M15, M16 risk alma eğilimi olarak; altıncı faktörde toplanan M26, M2, M27 proaktiflik/firsat keşfi olarak; yedinci faktörde toplanan M37, M9, M1 öz yeterlik olarak isimlendirilerek ölçeğe son hali verilmiştir. Nihai olarak ölçek 27 maddeden oluşmaktadır.

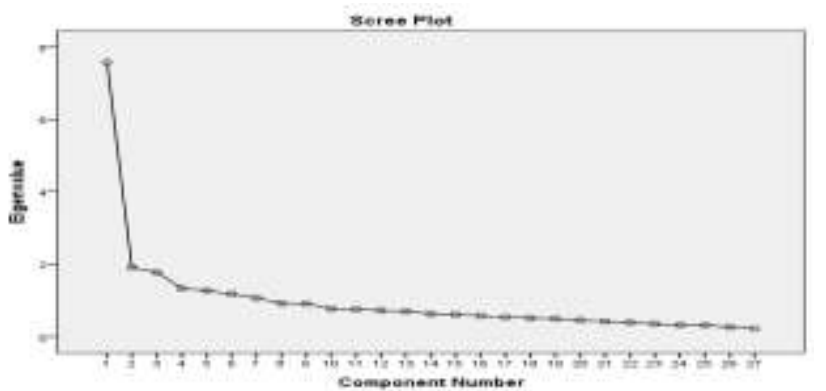

Şekil 1. İç Kontrol Odaklı Girişimcilik Ölçeğine Ait Özdeğer Saçılım Grafiği

Faktör sayısının belirlenmesinde kullanılan bir yöntem olan özdeğer saçılım grafiği ile faktör yapısı incelenmiştir. Ölçek faktör sayısının belirlenmesinde özdeğer saçılım grafiğinde yüksek ivmeli düşüşler dikkate alınmaktadır. Düşüşlerin yatay olduğu faktörlerin varyansa katkısının az olduğu düşünülmektedir (Büyüköztürk, 2011:133). Şekil 1 incelendiğinde 7 . faktörden sonra faktörlerin varyansa olan katkıları azalarak birbirine yaklaştığı görülmüştür. Özdeğerin 1'den yüksek olan faktörler önemli olarak değerlendirilmektedir (Koçak, Çokluk ve Kayri, 2016: 335-
337). Ölçeğin faktörlerine ait özdeğerlerin 1'in üzerinde olduğu görülmektedir. Buna göre; döndürülmüş bileşenler matrisi ve özdeğer saçılım grafiği değerlendirildikten sonra, literatürden elde edilen bilgilerden hareketle aynı zamanda istatistiksel sonuçların tutarlılığından yola çıkılarak geliştirilen ölçek 7 faktör altında toplanmıştır.

Ölçeğe ait oluşan faktör yapısı aşağıda görülmektedir.

Tablo 7. İç Kontrol Odaklı Girişimcilik Ölçeğine Ait Özdeğerler ve Faktörlerin Açıkladıkları Varyans Oranı

\begin{tabular}{|c|c|c|c|c|c|c|c|c|c|}
\hline \multicolumn{10}{|c|}{ Açıklanan Toplam Varyans } \\
\hline \multirow{2}{*}{ 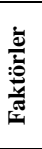 } & \multicolumn{3}{|c|}{$\begin{array}{c}\text { Başlangıç Özdeğerleri } \\
\text { Toplamları }\end{array}$} & \multicolumn{3}{|c|}{$\begin{array}{l}\text { Toplam Faktör } \\
\text { Yükleri }\end{array}$} & \multicolumn{3}{|c|}{$\begin{array}{c}\text { Faktör Yüklerinin } \\
\text { Döndürülmüss } \\
\text { Toplamları }\end{array}$} \\
\hline & Toplam & 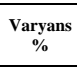 & $\begin{array}{c}\text { Kümülatif } \\
\%\end{array}$ & Toplam & $\begin{array}{c}\text { Varyans } \\
\%\end{array}$ & $\begin{array}{c}\text { Kümülati } \\
\text { f } \\
\% \\
\end{array}$ & Toplam & $\begin{array}{c}\text { Varyans } \\
\%\end{array}$ & $\begin{array}{c}\text { Kümülati } \\
\mathbf{f} \\
\% \\
\end{array}$ \\
\hline 1 & 7,577 & 28,061 & 28,061 & 7,577 & 28,061 & 28,061 & 3,776 & 13,986 & 13,986 \\
\hline 2 & 1,911 & 7,078 & 35,140 & 1,911 & 7,078 & 35,140 & 2,516 & 9,319 & 23,305 \\
\hline 3 & 1,778 & 6,585 & 41,724 & 1,778 & 6,585 & 41,724 & 2,238 & 8,289 & 31,594 \\
\hline 4 & 1,331 & 4,931 & 46,655 & 1,331 & 4,931 & 46,655 & 1,988 & 7,363 & 38,957 \\
\hline 5 & 1,273 & 4,715 & 51,370 & 1,273 & 4,715 & 51,370 & 1,980 & 7,333 & 46,290 \\
\hline 6 & 1,176 & 4,355 & 55,726 & 1,176 & 4,355 & 55,726 & 1,907 & 7,063 & 53,353 \\
\hline 7 & 1,069 & 3,958 & 59,684 & 1,069 & 3,958 & 59,683 & 1,709 & 6,330 & 59,683 \\
\hline 8 & ,923 & 3,417 & 63,101 & & & & & & \\
\hline 9 & ,913 & 3,381 & 66,482 & & & & & & \\
\hline 10 & ,770 & 2,854 & 69,335 & & & & & & \\
\hline 11 & ,750 & 2,779 & 72,114 & & & & & & \\
\hline 12 & ,723 & 2,677 & 74,791 & & & & & & \\
\hline 13 & ,704 & 2,606 & 77,397 & & & & & & \\
\hline 14 & ,631 & 2,336 & 79,734 & & & & & & \\
\hline 15 & ,608 & 2,254 & 81,987 & & & & & & \\
\hline 16 & ,574 & 2,127 & 84,114 & & & & & & \\
\hline 17 & ,536 & 1,987 & 86,101 & & & & & & \\
\hline 18 & ,510 & 1,891 & 87,991 & & & & & & \\
\hline 19 & ,499 & 1,846 & 89,838 & & & & & & \\
\hline 20 & ,449 & 1,665 & 91,503 & & & & & & \\
\hline 21 & ,424 & 1,570 & 93,072 & & & & & & \\
\hline 22 & , 390 & 1,445 & 94,517 & & & & & & \\
\hline 23 & ,354 & 1,311 & 95,828 & & & & & & \\
\hline 24 & ,321 & 1,191 & 97,018 & & & & & & \\
\hline 25 & ,313 & 1,160 & 98,178 & & & & & & \\
\hline 26 & ,269 & 996 996 & 99,174 & & & & & & \\
\hline 27 & ,223 &, 826 & $\begin{array}{c}100,00 \\
0\end{array}$ & & & & & & \\
\hline
\end{tabular}

Tablo 7'de Akademisyenlerin İç Kontrol Odaklı Girişimcilik Ölçeğinin faktör yapısını gösteren yedi faktörün özdeğerleri ve açıklanan varyansları yer almaktadır. Belirlenen yedi faktör, ölçeğe ait varyansın toplam \%59,683'ünü açıklamaktadır. Birinci faktör toplam varyansa \%13,986; ikinci faktör toplam varyansa \%9,319; üçüncü faktör toplam varyansa $\% 8,289$; dördüncü faktör toplam varyansa $\% 7,363$; beşinci faktör toplam varyansa \% 7,333 ; altıncı faktör toplam varyansa \%7, 063; yedinci faktör toplam varyansa $\% 6,330$ oranında katkı sağlamaktadır. Faktör analizinde elde edilen toplam varyans değeri $(\% 59,683) \% 40-\% 60$ arasında bir değer olduğundan ideal kabul edilmektedir (Scherer, Luther, Wiebe ve Adams, 1988: 766). 
Tablo 8. İç Kontrol Odaklı Girişimcilik Ölçeği Faktör Yapısı

Faktör
Boyut $\quad$ Yükü

Özgünlük (Özdeğer=7,577; Açıklanan Varyans=13,986;

Alpha=0,852)

18. özgün bir ürün ortaya koyma konusunda kendimi yeterli görürüm

0,755

19. çalışmalarımda yeni yöntemler denerim

0,746

21. çalışmaları daha işlevsel hale getirmek için yeni

fikirler üretebilirim

0,736

22. genellikle özgün konular üzerinde çalışmayı tercih ederim

0,670

20. yenilikçi projeleri uygulamaya koymak için

firsatlar yaratırım

0,650

17. yenilikleri mesleğimde ne şekilde

kullanabileceğimi bilirim

0,561

Kontrol (Özdeğer=1,911; Açıklanan Varyans=9,319;

Alpha $=0,759)$

6. yaptığım planlara uygun bir şekilde ilerleyebilirim $\quad 0,856$

5. hedeflerime ulaşmak için planlama sürecini kontrol

edebilirim

0,753

7. hedeflerime ulaşmak için engelleri kontrolümde tutmaya çalışırım

0,603

8. hedeflerime ulaşmak için kendimi motive edebilirim $\quad 0,502$

Özerklik (Özdeğer=1,778; Açıklanan Varyans=8,289;

Alpha=0,749)

30. yaptığım her eylemde, aldığım her kararda kontrol

bana aittir

0,744

29. amaçladığım bir şeyi gerçekleştirmek için

başkalarının desteğine ihtiyaç duymam

0,680

32. tek başıma özgün bir çalışma yürütebilirim

0,580

31. yapabileceklerim doğrultusunda hedefler belirlerim $\quad 0,460$

Başarma ihtiyacı (Özdeğer=1,331; Açıklanan Varyans=7,363;

Alpha=0,737)

\begin{tabular}{lc}
\hline 10. zor hedefler beni yıldırmaz & 0,681 \\
$\begin{array}{l}\text { 11. zayıf yönlerimi geliştirmeye çalışırım } \\
\begin{array}{l}\text { 13. bir konuda alacağım riskin sonuçlarını } \\
\text { üstlenebilirim }\end{array}\end{array}$ & 0,572 \\
$\begin{array}{l}\text { 4. hatalarımın olduğu durumlarda yeni bir strateji } \\
\text { belirleyebilirim }\end{array}$ & 0,470 \\
\hline
\end{tabular}

Risk alma eğilimi (Özdeğer=1,273; Açıklanan Varyans=7,333; Alpha=0,769)

\begin{tabular}{ll}
\hline $\begin{array}{l}\text { 14. yüksek getiri sağlayabilecek bir durum için } \\
\text { özveride bulunabilirim }\end{array}$ & 0,772 \\
$\begin{array}{l}\text { 15. karşılaştığım risk durumlarını kontrol edebilirim } \\
\begin{array}{l}\text { 16. risk alarak mesleğimde ilerleyebileceğimi } \\
\text { düşünürüm }\end{array}\end{array}$ & 0,596 \\
\hline
\end{tabular}

Proaktiflik /Fırsat keşfi (Özdeğer=1,176; Açıklanan

Varyans=7,063; Alpha $=0,788$ )

26. ortaya çıkan krizleri firsata çevirebilirim $\quad 0,797$

2. olumsuz durumları lehime çevirebilecek taktikler

kullanırım

27. bir projede yönlendiren ve /veya harekete geçiren taraf ben olurum

0,562

Öz yeterlik (Özdeğer=1,069; Açıklanan Varyans=6,330; Alpha $=0,801$ )

37. bir konuda başarı elde ettiğimde kendimle gurur duyarım

9. bir konuda elde ettiğim başarı üzerinde kendi çabamın etkili olduğunu bilirim

1. yeni bir şey öğrenirken güçlü yönlerimden faydalanırım

Toplam Varyans=\%59.683; Genel Güvenirlik (Alpha) $=0.894$
İç Kontrol Odaklı Girişimcilik Ölçeğinin belirlenmiş faktör yapısı doğrulayıc1 faktör analizi ile test edilmiştir. Doğrulayıcı Faktör Analizi, gözlenen değişkenler ile gizli değişkenler arasındaki ilişkiyi ölçebilen yapısal eşitlik modelinin bir çeşididir (Brown, 2015:10-11). Çalışmada literatürde bulunan araştırmalarda en sık kullanılan uyum iyiliği indeksleri kullanılmıştır. Doğrulayıcı faktör analize ilişkin diyagram aşağıda verilmektedir.

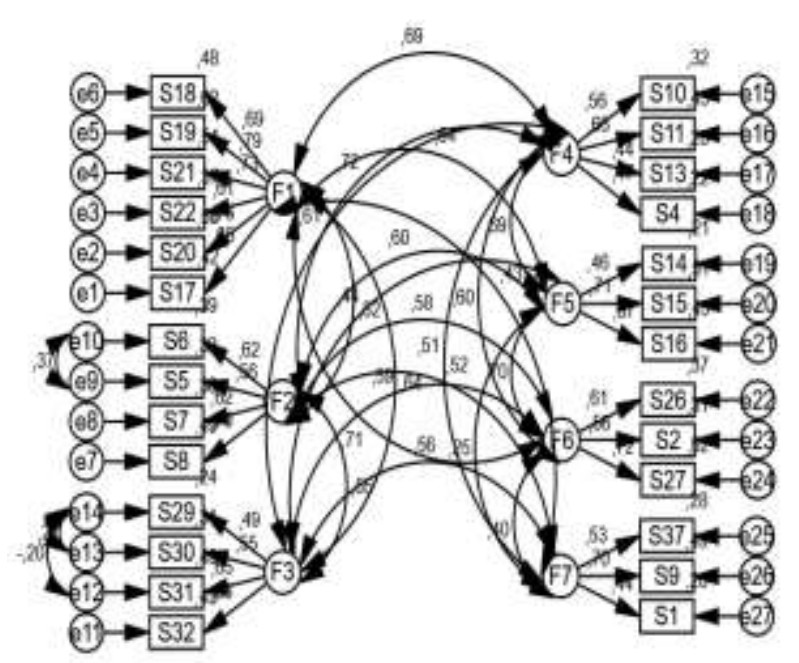

Şekil 2. İç Kontrol Odaklı Girişimcilik Ölçeği Doğrulayıcı Faktör Analizine İlişkin Diyagram

Doğrulayıcı faktör analizine ilişkin uyum iyiliği kriterleri aşağıda verilmektedir.

Tablo 9. İç Kontrol Odaklı Girişimcilik Ölçeği Doğrulayıcı Faktör Analizi İndeks Değerleri

\begin{tabular}{lccc}
\hline İndeks & $\begin{array}{c}\text { Normal } \\
\text { Değer* }\end{array}$ & $\begin{array}{c}\text { Kabul } \\
\text { Edilebilir } \\
\text { Değer** }\end{array}$ & $\begin{array}{c}\text { İç Kontrol Odaklı } \\
\text { Girişimcilik Ölçeği }\end{array}$ \\
\hline$\chi 2 /$ sd & $<2$ & $<5$ & $(615,980 / 3) 2,053$ \\
GFI & $>0,95$ & $>0,90$ & 0,90 \\
AGFI & $>0,95$ & $>0,90$ & 0,90 \\
CFI & $>0,95$ & $>0,90$ & 0,90 \\
RMSE & $<0,05$ & $<0,08$ & 0,06 \\
A & $<0,05$ & $<0,08$ & 0,04 \\
SRMR & & & \\
\hline
\end{tabular}

*,** Kaynaklar: (Şimşek, 2007:48; Schumacker ve Lomax, 2004: 82; Sümer, 2000:69; Tabachnick ve Fidel, 2013:721-723).

Tablo 9 incelendiğinde ki-kare değerinin serbestlik derecesine oranı 2 ve 5 değerleri arasında olduğundan kabul edilebilir bir uyumu göstermektedir. Bu durum model ile veri uyumunun sağlandığının bir göstergesi olarak değerlendirilmektedir. GFI değeri ,90 olarak hesaplanmış olduğundan kabul edilebilir değer kabul edilmektedir. AGFI değeri ,90 olarak hesaplanmış olduğundan kabul edilebilir değer kabul edilmektedir. CFI değeri ,90 olarak hesaplandığından kabul edilebilir değer olarak kabul edilmektedir. RMSEA değeri .06 olarak hesaplanmış olup normal değer olarak görülmektedir. SRMR değeri ,04 olarak hesaplanmış olduğundan normal değer olarak kabul edilmektedir. $\mathrm{Bu}$ bulgularla, doğrulayıcı faktör analizi ile hesaplanan uyum istatistiklerinin ölçeğin daha önce 
belirlenen faktör yapısı ile kabul edilebilir düzeyde uyumlu olduğu saptanmıştır

Standardize edilmiş faktör yükleri, $\mathrm{t}$ değerleri ve maddelerin oluşturduğu açıklanan varyans $\left(\boldsymbol{R}^{2}\right)$ değerleri aşağıda verilmektedir.

Tablo 10. İç Kontrol Odaklı Girişimcilik Ölçeği Faktör Yükleri ve Maddelere İlişkin Regresyon Katsayıları

\begin{tabular}{|c|c|c|c|c|c|c|c|c|}
\hline Maddeler & & Faktör & $\beta$ & Std. $\beta$ & $\begin{array}{c}\text { S. } \\
\text { Hata }\end{array}$ & $\mathbf{t}$ & p & $R^{2}$ \\
\hline S17 & $\begin{array}{l}<- \\
--\end{array}$ & F1 & 1,000 & 0,650 & & & & 0,455 \\
\hline S20 & $\begin{array}{l}<- \\
--\end{array}$ & $\mathrm{F} 1$ & 1,640 & 0,762 & 0,151 & 10,860 & $\mathrm{p}<0,001$ & 0,490 \\
\hline S22 & $\begin{array}{l}<- \\
--\end{array}$ & $\mathrm{F} 1$ & 1,035 & 0,608 & 0,115 & 9,026 & $\mathrm{p}<0,001$ & 0,485 \\
\hline $\mathrm{S} 21$ & $\begin{array}{l}<- \\
--\end{array}$ & $\mathrm{F} 1$ & 1,199 & 0,733 & 0,114 & 10,537 & $\mathrm{p}<0,001$ & 0,522 \\
\hline S19 & $\begin{array}{l}<- \\
--\end{array}$ & $\mathrm{F} 1$ & 1,450 & 0,790 & 0,130 & 11,166 & $\mathrm{p}<0,001$ & 0,532 \\
\hline S18 & $\begin{array}{l}<- \\
--\end{array}$ & $\mathrm{F} 1$ & 1,419 & 0,691 & 0,141 & 10,050 & $\mathrm{p}<0,001$ & 0,561 \\
\hline S8 & $\begin{array}{l}<- \\
--\end{array}$ & $\mathrm{F} 2$ & 1,000 & 0,702 & & & & 0,452 \\
\hline S7 & $\begin{array}{l}<- \\
--\end{array}$ & $\mathrm{F} 2$ & 0,852 & 0,615 & 0,102 & 8,365 & $\mathrm{p}<0,001$ & 0,509 \\
\hline S5 & $\begin{array}{l}<- \\
--\end{array}$ & $\mathrm{F} 2$ & 0,742 & 0,564 & 0,097 & 7,652 & $\mathrm{p}<0,001$ & 0,478 \\
\hline S6 & $\begin{array}{l}<- \\
--\end{array}$ & $\mathrm{F} 2$ & 0,895 & 0,625 & 0,107 & 8,362 & $\mathrm{p}<0,001$ & 0,563 \\
\hline S32 & $\begin{array}{l}<- \\
--\end{array}$ & F3 & 1,000 & 0,653 & & & & 0,527 \\
\hline S31 & $\begin{array}{l}<- \\
--\end{array}$ & F3 & 0,730 & 0,655 & 0,091 & 8,025 & $\mathrm{p}<0,001$ & 0,432 \\
\hline $\mathrm{S} 30$ & $\begin{array}{l}<- \\
--\end{array}$ & F3 & 0,816 & 0,553 & 0,113 & 7,200 & $\mathrm{p}<0,001$ & 0,547 \\
\hline S29 & $\begin{array}{l}<- \\
--\end{array}$ & F3 & 0,852 & 0,490 & 0,139 & 6,116 & $\mathrm{p}<0,001$ & 0,501 \\
\hline S10 & $\begin{array}{l}<- \\
--\end{array}$ & F4 & 1,000 & 0,563 & & & & 0,409 \\
\hline S11 & $\begin{array}{l}<- \\
--\end{array}$ & $\mathrm{F} 4$ & 0,982 & 0,657 & 0,129 & 7,594 & $\mathrm{p}<0,001$ & 0,429 \\
\hline S13 & $\begin{array}{l}<- \\
--\end{array}$ & $\mathrm{F} 4$ & 0,638 & 0,444 & 0,109 & 5,847 & $\mathrm{p}<0,001$ & 0,426 \\
\hline S4 & $\begin{array}{l}<- \\
--\end{array}$ & $\mathrm{F} 4$ & 0,623 & 0,473 & 0,102 & 6,128 & $\mathrm{p}<0,001$ & 0,444 \\
\hline S14 & $\begin{array}{l}<- \\
--\end{array}$ & F5 & 1,000 & 0,463 & & & & 0,469 \\
\hline S15 & $\begin{array}{l}<- \\
--\end{array}$ & F5 & 1,216 & 0,713 & 0,185 & 6,580 & $\mathrm{p}<0,001$ & 0,433 \\
\hline S16 & $\begin{array}{l}<- \\
--\end{array}$ & F5 & 1,809 & 0,672 & 0,280 & 6,468 & $\mathrm{p}<0,001$ & 0,493 \\
\hline S26 & $\begin{array}{l}<- \\
--\end{array}$ & F6 & 1,000 & 0,609 & & & & 0,477 \\
\hline $\mathrm{S} 2$ & $\begin{array}{l}<- \\
--\end{array}$ & F6 & 0,922 & 0,561 & 0,127 & 7,280 & $\mathrm{p}<0,001$ & 0,625 \\
\hline S27 & $\begin{array}{l}<- \\
--\end{array}$ & F6 & 1,175 & 0,723 & 0,139 & 8,466 & $\mathrm{p}<0,001$ & 0,537 \\
\hline S37 & $\begin{array}{l}<- \\
--\end{array}$ & F7 & 1,000 & 0,529 & & & & 0,469 \\
\hline S9 & $\begin{array}{l}<- \\
--\end{array}$ & F7 & 1,130 & 0,700 & 0,191 & 5,929 & $\mathrm{p}<0,001$ & 0,580 \\
\hline S1 & $\begin{array}{l}<- \\
--\end{array}$ & F7 & 0,641 & 0,442 & 0,126 & 5,081 & $\mathrm{p}<0,001$ & 0,422 \\
\hline
\end{tabular}

Standardize edilmiş katsayılar incelendiğinde faktör yüklerinin yüksek, standart hata değerlerinin düşük, t değerlerinin anlamlı $(\mathrm{p}<0,001), \boldsymbol{R}^{2}$ değerlerinin yüksek olduğu belirlenmiştir. Bu sonuçlar önceden belirlenen faktör yapısına ilişkin yapı geçerliliğini doğrulamaktadır.

\section{İç Kontrol Odaklı Girişimcilik Ölçeğinin Güvenilirlik Çalışmaları ile İlgili Bulgular}

Literatürde ölçeğin güvenirliği (iç tutarlılık) yaygın olarak Cronbach's Alpha katsayısı ile belirlenmektedir. Cronbach's
Alpha Katsayısının değerlendirilmesinde kullanılan değerlendirme kriteri olarak " $0,00 \leq \alpha<0,40$ ise ölçek güvenilir değildir", " $0,40 \leq \alpha<0,60$ ise ölçek düşük güvenilirliktedir", " $0,60 \leq \alpha<0,80$ ise ölçek oldukça güvenilirdir", " $0,80 \leq \alpha<1,00$ ise ölçek yüksek derecede güvenilir bir ölçektir" olarak belirlenmektedir (Özdamar, 2017:79). Nihai formun genel güvenirliği Cronbach Alpha $=0,894$ olarak çok yüksek bulunmuştur.Özgünlük boyutu, Alpha $=0,852$; Kontrol boyutu, Alpha=0,759; Özerklik boyutu, Alpha=0,749; Başarma ihtiyacı boyutu, 0,737; risk alma eğilimi boyutu, Alpha=0,769; proaktiflik/firsat keşfi boyutu, Alpha=0,788; Öz yeterlik boyutu, Alpha=0,801 olarak bulunmuştur. Ölçeğin güvenirliğine ilişkin bulunan Cronbach Alpha değeri $(0,894)$ ve açıklanan varyans değerine $(\% 59,683)$ göre İç Kontrol Odaklı Girişimcilik Ölçeğinin geçerli ve güvenilir bir araç olduğu anlaşılmıştır.

Tablo 11. Ölçek Puanlarının Alt \%27 ve Üst \%27 Gruplarına Göre Farklılaşma Durumu

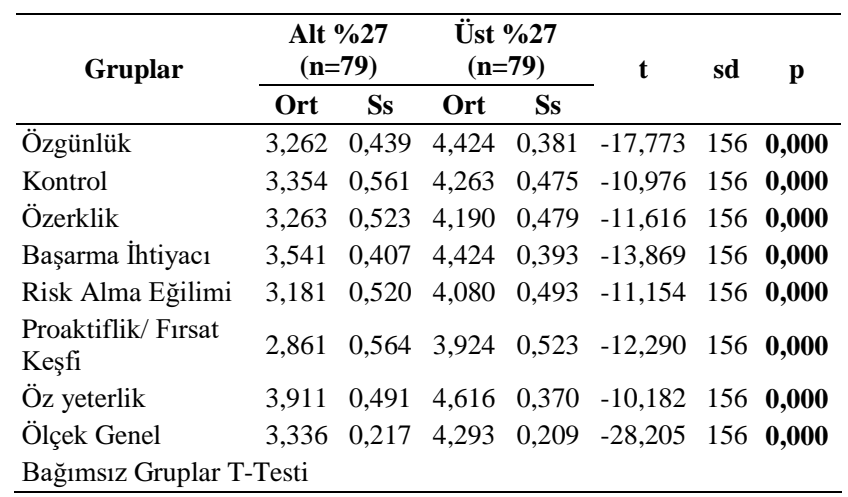

Tablo 11'de görüldüğü üzere ölçek puanları Alt \%27 ve Üst $\% 27$ gruplarına göre farklılık göstermektedir $(p<0,05)$. Ölçek puanları dağılımında ölçülmek istenen tutuma olumlu yanıt veren katılımcılar üst \%27'lik grupta olumsuz yanıt veren katılımcılar ise alt \%27'lik grupta yer almaktadır. Eğer bir madde bahsedilen gruplardaki tepkileri ayırt edebiliyorsa ölçülen tutuma olumlu yanıt verenler ile olumsuz yanıt verenleri ayırt edebiliyordur. Bu durum bireylerin ölçülen davranışı ne derece ayırt ettiğini göstermektedir. Çok boyutlu ölçeklerde ise alt ve üst \%27 grupların her bir boyut için tanımlanması gerekmektedir (Büyüköztürk et al., 2015; Tezbaşaran, 1996). Yukarıda verilen tablodaki bulgulara dayanarak geliştirilen ölçek, iç-tutarlılık açısından da ölçeğin ayırt edici ölçüm yaptığı ve ölçekten elde edilen puanların güvenilir olduğunu göstermektedir.

\section{Tartışma, Sonuç ve Öneriler}

$\mathrm{Bu}$ araştırma; bir dizi faktörün işlevi olan ve girişimci kişiliğin, sosyo-ekonomik bir sistemde mevcut firsatlar, girişimci tutum, beceri ve davranışların geliştirilmesi için destek pozisyonda olduğu kabul edilen girişimcilik kavramını (Pandey \& Tewary, 1979; Valdez, 2019; Wickham, 2001) iç kontrol odaklı bir perspektiften ele alarak değerlendiren bir ölçek geliştirme çalışmasıdır. Girişimciliğin, ülke ekonomilerinin büyümesine aracılık eden önemli unsurlardan biri olmas1 (Bhole, 2007; Dayal, 2007; Hisrich ve Peters, Shepherd, 2016) araştırma konusu olarak popüler hale gelmesine katkı sağlamıştır. Girişimcilik konusunda yapılan çalışmalar, toplumlara girişimcilik kavramları ve bileşenleri hakkında aynı zamanda ekonomi alanlarında öneriler sunmaktadır. $\mathrm{Bu}$ çalışmada ise; literatürde ilk olarak girişimcilik konusuna girişimcilik özelliklerinden biri olan iç kontrol odaklı bir çerçeveden bakılarak akademisyenlerin iç 
kontrol odaklı girişimcilik eğilimlerini değerlendirmek üzere bir ölçek geliştirilmiştir. Bu anlamda, 3. nesil üniversite olmanın zorunluluklarından biri olan girişimcilik boyutunun değerlendirilmesi yönüyle alana katkı sağlayacak niteliktedir. Küreselleşmenin gereklilikleri ile birlikte hayatın her alanında olduğu gibi eğitim alanında da her tür değişime hızlı bir şekilde adapte olunması gerekmektedir. Yükseköğretim kurumlarının da bu adaptasyon sürecinde toplumsal dönüşümde aracı bir rol üstlenmesi gerekmektedir. $\mathrm{Bu}$ aracılık rolü zaman içerisinde yükseköğretim kurumlarını girişimci ekosistemde ana kahraman haline getirmiştir. Yükseköğretim kurumları; araştırma odaklı, bilimsel içeriğe sahip, kişileri düşünmeye ve eylemlerini kontrol etmeye yönlendiren kurumlardır. Aynı zamanda yaratıcılığı besleyen, ortamlarda fikir ve bilgi paylaşımı aracılığ ile topluma katkı sağlayan proaktif davranışa yönelik beceriler kazandırma konusunda kilit roldeki kurumlardır (Çetin ve Kınık, 2019; Ramirez vd., 2015). Bu süreçte yükseköğretim kurumları için ana motivasyon kaynağı; entelektüel sermayeyi güçlendirmenin yanı sıra üretilen bilginin ekonomik kalkınmayı teşvik edecek nitelikte kullanılmasıdır. Bu eylemlerini gerçekleştirmesinin yolu ise; araştırma, öğretim ve farklı kurumlarla etkileşim kurmak gibi üç temel misyon aracılığıyla girişimci faaliyetler yaratmayı desteklemektir. Öyle ki gerçekleştirilen girişimcilik faaliyetleri, yükseköğretim kurumlarının küresel şartlardaki akademik kültürünü oluşturan ve uluslarasılaşmasını destekleyen bir değer olarak kabul edilebilir. Bu dönüşüm sürecinin yönetilmesinde arac1 rolü üstlenen akademisyenlerden daha fazla verim elde edilebilmesi için yükseköğretim kurumlarının işlevlerinin akademisyenlerin girişimcilikleri çerçevesinde değerlendirilmesi önemlidir. Girişimciliğe ilişkin mikro görüş; girişimciliğe özgü iç kontrol odağının parçası olan faktörleri incelemektedir (Frederick, O'Connor, \& Kuratko, 2016). Çalışmalar, iç kontrol yapısını, kendi kendine öğrenme, alan bağımsızlığı ve öğrenen özerklik yapılarıyla ilişkilendirmiştir. Bu özelliklere sahip bireylerin hedeflerine ulaşma olasılıklarının daha yüksek olduğu yönünde sonuçlar elde edilmiştir (Besich, 2005). Başka bir ifadeyle kontrol odağı becerisi girişimci özelliklere sahip olan kişilerle bu özellikleri taşımayan yani girişimci olmayan bireyler arasında ayırım yapmayı sağlayan önemli bir kavramdır. Bu farkı daha belirgin hale getiren kavram ise iç kontrol odağıdır (Begley, \& Boyd, 1987; Brockhaus, 1979; Caird, 1991; Kaufmann et al., 1995; Kets De Vries, 1977; Perry, 1990). Aynı zamanda Korunka et al., (2003) yüksek başarma ihtiyacı, yüksek iç kontrol odağı ve orta risk alma eğilimi ile karakterize edilen bir kişilik modeli bulmuşlardır. Bu durum potansiyel girişimcinin, eylemlerini yönlendirme veya ayarlama yeteneğine sahip olduğu gerçeğini doğrulamaktadır (Frederick, O'Connor, \& Kuratko, 2016). Bu yetenek aracılığılla beklenmedik bir durum ile karşılaşıldığ 1 durumlarda dahi kişisel kontrol devreye girerek kişinin duygularından bağımsız olarak daha sağlıklı ve doğru kararlar almasına yardımcı olmaktadır (Tarhan, 2019). Bu durum potansiyel girişimcinin, eylemlerini yönlendirme veya ayarlama yeteneğine sahip olduğu gerçeğini doğrulamaktadır (Frederick vd., 2016). Carland ve diğerlerine (1984) göre girişimci bireylerin başarı motivasyonu yüksektir, orta derecede risk alırlar, inovasyon yaparlar ve içsel kontrol odağına sahiptirler. Lumpkin ve Dess (2001) yenilikçi veya yeni girişim aktivitesinin ileriye dönük ve proaktif bir bakış açısı önerdiğini ortaya koymuştur. Yapılan araştırmalara bakıldığında; elde edilen 7 boyutlu yapının literatürü destekler şekilde olduğu ortaya çıkmıştır.

Akademisyenlerin iç kontrol odaklı girişimcilik eğilimlerini ölçmek amaciyla oluşturulan ölçek formuna faktör analizi uygulanmış bu uygulama sonucunda ölçeğin nihai hali 27 madde olarak belirlenmiştir. Geçerlik güvenirlik çalışması sürecinde öncelikle yapı geçerliliğini ortaya çıkarmak için açımlayıcı ve doğrulayıcı faktör analizleri daha sonra ölçeğin ayırt ediciliğini tespit etmek için ayırt edicilik analizi yapılmıştır. Ölçülmek istenen yapının iç tutarlılığını tespit edebilmek için Cronbach Alpha katsayı değerleri dikkate alınmıştır. Yapılan bu analizler sonucunda ulaşılan sonuçlar aşağıda verilmiştir.

- Yapılan analizler sonucunda geliştirilen "İç Kontrol Odaklı Girişimcilik Ölçeği” 7 faktörlü olarak belirlenmiştir.

- İç kontrol odaklı girişimcilik ölçeği için belirlenen boyutlar; özgünlük, özerklik, kontrol, başarma ihtiyacı, risk alma eğilimi, proaktiflik/fırsat keşfi ve öz yeterlik olarak isimlendirilmiştir.

- İç Kontrol Odaklı Girişimcilik Ölçeğinin belirlenmiş olan faktör yapısı doğrulayıcı faktör analizi ile test edilmiştir. Analiz sonucunda, doğrulayıcı faktör analizi ile hesaplanan uyum istatistiklerinin ölçeğin daha önce belirlenen faktör yapısı ile uyumlu olduğu saptanmıştır.

- Standardize edilmiş katsayılar incelendiğinde önceden belirlenen faktör yapısına ilişkin yapı geçerliliği doğrulanmıştır.

- Ölçeğin ayırt ediciliğine ilişkin olarak yapılan analiz sonucunda ölçeğin ayırt edici ölçüm yaptığı saptanmıştır.

- “İç Kontrol Odaklı Girişimcilik Ölçeği”ne ilişkin güvenirlik analizi uygulanmış ve Alpha katsayısı; 0.894 olarak çok yüksek bulunmuştur. Özgünlük boyutu; Alpha $=0,852$, kontrol boyutu; Alpha $=0,759$, özerklik boyutu; alpha=0,749, başarma ihtiyacı boyutu; Alpha=0,737, risk alma eğilimi boyutu; Alpha=0,769, proaktiflik- firsat keşfi boyutu; Alpha $=0,788$, öz yeterlik boyutu; Alpha=0,801 olarak belirlenmiştir.

- Sonuç olarak yapılan analizler doğrultusunda iç kontrol odaklı girişimcilik ölçeğinin akademisyenlerin girişimcilik eğilimlerini ölçebilecek geçerliliğe ve güvenirliğe sahip olduğu tespit edilmiştir. Geliştirilen iç kontrol odaklı girişimcilik ölçeği ile özellikle yükseköğretim kurumlarında girişimciliğin fark edilmesi, anlaşılması, benimsenmesi ve girişimcilik eğilimlerinin tespit edilmesi sağlanabilir. Daha geniş ve faydalı kazanımlar elde edebilmek için akademisyenlerin girişimciliğini kişilik özellikleri, liderlik becerileri, kurum kültürü gibi farklı değişkenlerle ele alarak farkındalık oluşturacak alanların kapsamının genişletilmesi sağlanabilir. Girişimci akademisyenlerle görüşmeler yapılarak araştırma konusunun nitel yöntemlerle ele alınması gerçekleştirilebilir. Ayrıca yükseköğretim kurumlarındaki girişimciliğin kültürler arasındaki farklılığını tespit edebilmek için daha kapsamlı araştırmalar yapılabilir. 


\section{Kaynakça}

Aaker, D. A., Kumar, V., \& Day, G. S. (2007). Marketing research (9th Edition). England: John Wiley \& Sons, Danvers.

Ağça, D. V. ve Yumuşakipek, A. H. (2015). Günümüzde girişimcilik trendini yükselten güçler. İstanbul: Siyah İnci Akademi.

Anderson, C. R. (1977). Locus of control, coping behaviors, and performance in a stress setting: A longitudinal study. Journal of Applied Psychology, 62(4), 446-451.

Antonic, B., \& Hisrich, R. D. (2001). Interpreneurship: Construct refinement and cross cultural validation. Journal of Business Venturing, 16(5), 495-527.

Aparicio, S., Urbano, D., \& Audretsch, D. (2016). Institutional factors, opportunity entrepreneurship and economic growth: Panel data evidence. Technological Forecasting and Social Change, 102, 45-61.

Bandura, A. (1982). Self-efficacy mechanism in human agency. American Psychologist, 3(2), 122-147.

Bandura, A. (2002). Growing primacy of human agency in adaptation and change in the electronic era. European Psychologist, 7(1), 2-16.

Bateman, T. S., \& Crant, J. M. (1993). The proactive component of organizational behavior: A measure and correlates. Journal of Organizational Behavior, 14(2), 103-118.

Bayrakçı, S. (2020). Dijital yetkinlikler bütünü olarak dijital okuryazarlık: Ölçek geliştirme çalışması (Doktora tezi). Marmara Üniversitesi, Sosyal Bilimler Enstitüsü, Gazetecilik Anabilim Dalı Bilişim Bilim Dalı, İstanbul.

Begley, T. M., \& Boyd, D P. (1987). Psychological characteristics associated with performance in entrepreneurial firms and smaller businesses. Journal of Business Venturing, 2, 79-93.

Bernardi, R. A. (2001, June). A theoretical model for the relationship among: Stress, locus of control, and longevity. In Business Forum, 26(3-4), 27-34. Los Angeles: California State University.

Besich, M. A. (2005). Learning tactics of successful online learners (Doctoral dissertation). Montana State University-Bozeman, College of Education, Health \& Human Development. Montana.

Bhole, L. M. (2007). The evolution of the concept of enterpreneurship. Bhargava, S. (Ed.). Developmental aspects of entrepreneurship. India: SAGE Publications.

Birch, D. L. (1987). Job creation in America: How our smallest companies put the most people to work. New York: Free Press.

Borland, C. M. (1975). Locus of control, need for achievement and entrepreneurship (Doctoral dissertation). The University of Texas At Austin, ProQuest Information \& Learning.

Brockhaus, R. H. (1975). I-E locus of control scores as predictors of entrepreneurial intentions. Academy of Management Proceedings, (1), 433-435. doi:10.5465/ ambpp.1975.4990354.
Brockhaus, R. H., \& Nord, W. R. (1979). An exploration of factors affecting the entrepreneurial decision: Personal characteristics versus environmental conditions. Academy of Management Proceedings, 1, 364-368. doi:10.5465/ambpp.1979.4977621.

Brown, T. A. (2015). Confirmatory factor analysis for applied research. London: Guilford Publications.

Büyüköztürk, Ş. (2002). Faktör analizi: Temel kavramlar ve ölçek geliştirmede kullanımı. Kuram ve Uygulamada Egitim Yönetimi Dergisi, 8(4), 470-483.

Büyüköztürk, Ş. (2006). Sosyal bilimler için veri analizi el kitabl. istatistik, araştırma deseni, SPSS uygulamaları ve yorumu. Ankara: Pegem Akademi.

Büyüköztürk, Ş. (2011). Deneysel desenler: Öntest-sontest kontrol grubu, desen ve veri analizi. Ankara: Pegem Akademi.

Büyüköztürk, Ş. (2014). Deneysel desenler: Öntest-sontest, kontrol grubu, desen ve veri analizi. Ankara: Pegem A.

Büyüköztürk, Ş., Akgün, Ö. E., Demirel, F., Karadeniz, Ş., ve Çakmak, E. K. (2015). Bilimsel araştırma yöntemleri. Ankara: Pegem Akademi.

Büyüköztürk, Ş., Çakmak, E. K., Akgün, Ö. E., Karadeniz, Ş., ve Demirel, F. (2016). Bilimsel araştırma yöntemleri. Ankara: Pegem Akademi.

Caird, S. (1991). Testing enterprising tendency in occupational groups. British Journal of Management, 2(4), 177-186.

Campbell, C. A. (1992). A decision theory model for entrepreneurial acts. Entrepreneurship Theory and Practice, 17(1), 21-27. doi:10.1177/104225879201700 103.

Carland, J., Hoy, F., \& Boulton, R. (1984). Differentiating entrepreneurs from small business owners: A conceptualization. Academy of Management Review, (9), 354-359.

Chirkov, V. (2014). The universality of psychological autonomy across cultures: Arguments from developmental and social psychology. Weinstein. $\mathrm{N}$ (Ed.). In Human motivation and interpersonal relationships (27-51). Dordrecht: Springer.

Collier, P. M., Berry, A. J., \& Burke, G. T. (2007). Risk and management accounting: Best practice guidelines for enterprise-wide internal control procedures, 2(11), 1151. New York: Elsevier.

Collins, C. J., Hanges, P. J., \& Locke, E. A. (2004). The relationship of achievement motivation to entrepreneurial behavior: A meta-analysis. Human Performance, 17(1), 95-117.

Covey, S. R. (1989). Etkili insanin yedi alışkanlı̆̆g. (G. Suveren \& O. Deniztekin, Çev.). İstanbul: Varlık Yayınları.

Çapık, C. (2014). Geçerlik ve güvenirlik çalışmalarında doğrulayıc1 faktör analizinin kullanımı. Anadolu Hemşirelik ve Sağlık Bilimleri Dergisi, 17(3), 196-205.

Çetin, M., ve Kınık-Fayda, F. Ş. (2019). Yükseköğretimde bilgi yönetimi. Ankara: Nobel Akademik Yayıncılık. 
Çokluk, Ö., Şekercioğlu, G. ve Büyüköztürk, Ş. (2018). Sosyal bilimler için çok değişkenli istatistik: SPSS ve LISREL uygulamaları. Ankara: Pegem Akademi Yayıncilık.

Dağ, İ. (2002). Kontrol odağı ölçeği (KOÖ): Ölçek geliştirme, güvenirlik ve geçerlik çalışması. Türk Psikoloji Dergisi, 17(49), 77-90.

Dayal, I. (2007). Towards developing entrepreneurship and building entrepreneurial organizations. Bhargava, S. (Ed.). In Developmental aspects of entrepreneurship (3443). Sage Publications: Singapore.

Deci, E. L., \& Ryan, R. M. (1980). The empirical exploration of intrinsic motivational processes. Advances in Experimental Social Psychology, 13, 3980. doi:10.1016/s0065-2601(08)60130-6.

Deci, E. L., \& Ryan, R. M. (2014). Autonomy and need satisfaction in close relationships: Relationships motivation theory. N. Weinstein (Ed). In Human motivation and interpersonal relationships (53-73). Dordrecht: Springer.

Demirkan, S. (2006). Self-perceptions of interpersonal relations, conflict resolution approaches in locus of control and their effects on the structure of personality: A study in applied. Unpublished Master's Thesis, Ankara University, Social Sciences Institute, Ankara.

Dewi, D. K., \& Hamdani, A. R. (2019, August). Entrepreneurship development in higher education by growing motivation and utilizing opportunities for entrepreneurship. In International Conference of One Asia Community, 1(1), 110-113.

Drucker, P. F. (1985). The discipline of innovation. Harvard Business Review, 63(3), 67-72.

DuCette, J., \& Wolk, S. (1973). Cognitive and motivational correlates of generalized expectancies for control. Journal of Personality and Social Psychology, 26(3), 420-426. https://doi.org/10.1037/h0034486.

Fayolle, A., \& Klandt, H. (Ed.). (2006). International entrepreneurship education: Issues and newness. USA: Edward Elgar Publishing.

Flammer, A. (2001). Self-efficacy. International Encyclopedia of the Social \& Behavioral Sciences, 13812-13815. DOI: 10.1016/B0-08-043076-7/01726-5.

Frederick, H., O’Connor, A., \& Kuratko, D. F. (2016). Entrepreneurship (4th Edition). A.U. Cengage \& D. F. Kuratko (Eds.) Entrepreneurship theory, process, and practice. Australia: South-Western College Publication.

Gaglio, C. M. (1997). Opportunity identification: Review, critique, and suggested researchdirections. J. Katz (Ed.), In Advances in entrepreneurship, firm emergence and, growth. Greenwich, CT: JAI Press.

Gaglio, C. M., \& Katz, J. A. (2001). The psychological basis of opportunity identification: Entrepreneurial alertness. Small Business Economics, 16(2), 95-111.

Gelderen, M. V. (2016). Entrepreneurial autonomy and its dynamics. Applied Psychology, 65(3), 541-567.
Graffeo, L., \& Silvestri, L. (2006). Relationship between locus of control and health-related variables. Education, 126, 593-597.

Hair, J. F., Black, W. C., Babin, B. J., Anderson, R. E., \& Tatham, R. L. (1998). Multivariate data analysis. New York: Perason.

Hall, J. C., \& Sobel, S. R. (2006). Public policy and entrepreneurship. The Center for Applied Economics, $6(7), 1-18$.

Hassan, S. Z., Li, H., Kamal, T., Mumtaz, S., Khan, L., \& Ullah, I. (2016). Control and energy management scheme for a PV/SC/battery hybrid renwable power system. Science International, 28(2), 955-964.

Hermawan, R. W., Soetjipto, B. E., \& Rahayu, W. P. (2016). The effect of entrepreneurial self-efficacy and locus of control on entrepreneurship interest through entrepreneurship literacy. IOSR Journal of Business and Management (IOSR-JBM), 18(2), 141-148.

Hisrich, R. D., Peters, M. P., \& Shepherd, D. A. (2016). Entrepreneurshin (10th Edition). New York: McGrawHill Education.

İncik, E. Y., ve Uzun, N. B. Bireysel girişimcilik algı ölçeği geçerlik ve güvenirlik çalışması. Mustafa Kemal Üniversitesi Sosyal Bilimler Enstitüsü Dergisi, 14(39), 471-485.

Karasar, N. (2012). Bilimsel araştırma yöntemi. Ankara: Nobel Yayın Dağıtım.

Kaufmann, P. J., Welsh, D. H. B., \& Bushmarın, N. V. (1995). Locus of control and entrepreneurship in the russian republic. Entrepreneurship, 20(1), 43-56. DOI: $10.1177 / 104225879502000103$.

Kets De Vries, M. F. R. (1977). The entrepreneurial personality: A person at the crossroads. Journal of Management Studies, 14(1), 34-57.

Kim, D., \& Lee, D. (2018). Impacts of metacognition on innovative behaviors: Focus on the mediating effects of entrepreneurship. Journal of Open Innovation: Technology, Market, and Complexity, 4(18), 1-9.

Kirzner, I. (1979). Perception, opportunity, and profit. Chicago: University of Chicago Press.

Koçak, D., Çokluk, Ö., ve Kayri, M. (2016). Faktör sayısının belirlenmesinde MAP testi, paralel analiz, K1 ve yamaç birikinti grafiği yöntemlerinin karşılaştırılması. Yüzüncü Yıl Üniversitesi Ĕ̌itim Fakültesi Dergisi, 13(1), 330359.

Koh, H. C. (1996). Testing hypotheses of entrepreneurial characteristics a study of Hong Kong MBA students. Journal of Managerial Psychology, 11(3), 12-25.

Korunka, E., Frank, H., Lueger, M., \& Mugler, J. (2003). The entrepreneurial personality in the context of resources, environment, and the startup process-a configurational approach. Entrepreneurship Theory and Practice, 28(1), 23-42.

Köybaşı, F., ve Dönmez, B. (2017). Principal entrepreneurship scale: Validity and reliability study. 
Inönü Üniversitesi Eğitim Fakültesi Dergisi, 18, 235247.

Kuratko, D. F. (2015). The Oxford handbook of creativity, innovation and entrepreneurship. C. E. Shalley, M. A. Hitt, ve J. Zhou (Ed.). Corporate entrepreneurship: Accelerating creativity and innovation in organizations (477-488). Newyork: Oxford University Press doi:10.1093/oxfordhb/9780199927678.001.0001.

Kuratko, D., \& Hodgetts, R., (2001). Entrepreneurship: A contemporary approach. USA: Harcourt.

Kusumawijaya, I. K. (2019). The prediction of need for achievement to generate entrepreneurial intention: A locus of control mediation. International Review of Management and Marketing, 9(4), 54-62.

Lawshe, C. H. (1975). A quantitative approach to content validity. Personel Psychology, 28, 563-575.

Lefcourt, H. (1984). Locus of control: Current trends in theory and research. 2nd ed. Hilisdale, NJ: Lawrence Erlbaum.

Lefcourt, H. M., Martin, R. A. \& Fick, C. M. (1985). Locus of control for affi lliation and behavior in social interactions. Journal of Personality and Social Psychology, 48, 755-759.

Loosemore, M., \& Lam, A. S. Y. (2004). The locus of control: A determinant of opportunistic behaviour in construction health and safety. Construction Management and Economics, 22, 385-394.

Lumpkin, G. T., \& Dess, G. G., (1996). Clarifying the entrepreneurial orientation construct and linking it to performance. Academy of Management Review, 21(1), $135-172$.

Lumpkin, G., \& Dess, G. G. (2001). Linking two dimensions of entrepreneurial orientation to firm performance: The moderating role of environment and industry life cycle. Journal of Business Venturing, 16, 429-451.

Luthje, C., \& Franke, N. (2003). The making of an entrepreneur: Testing a model of entrepreneurial intent among engineering students at mit. $R \& D$ Management, $33(2), 135-147$.

Malhotra, N. K. (2010). Marketing research: An applied orientation. Sixth Edition Pearson Education.

McClelland, D. C. (1965). N Achievement and entrepreneurship: A longitudinal study. Journal of Personality and Social Psychology, 1(4), 389-392. https://doi.org/10.1037/h0021956.

McDougall, P. P. (1989). International versus domestic entrepreneurship: New venture strategic behavior and industry structure. Journal of Business Venturing, 4(6), 388-400.

Mihi-Ramírez, A., Fernández-Bendito, V., \& Valodkienė, G. (2015). Acquisition of technological competences in the university as a driver of entrepreneurship. Kusio, T., Makowiec, M. (Ed). Entrepreneurship management, 38(1), 43-60.
Mill, J. S. (1848). Principles of political economy with some of their applications to social philosophy. Boston: C. C. Little and Brown.

Miller, K. D. (2007). Risk and rationality in entrepreneurial processes. Strategic Entrepreneurship Journal, 1(1-2), 57-74.

Morishita, S. (2019, December). Motivation of entrepreneurs for service innovation. In 2019 4th Technology Innovation Management and Engineering Science International Conference (1-5). IEEE. doi: 10.1109/TIMES-iCON47539.2019.9024533.

Naji, A. A. H. (2019). Factors influencing entrepreneurship development. (Erişim:18.10.2020),

https://www.researchgate.net/profile/Amat_Alsalam_Na ji/publication/332255136_Factors_Influencing_Entrepre neurship_Development/links/5ca9ddb692851c64bd5639 aa/Factors-Influencing-Entrepreneurship Development.pdf

Oliver, J. E., Jose, P. E., \& Brough, P. (2006). Confirmatory factor analysis of the work locus of control scale. Educational and Psychological Measurement, 66(5), 835-851.

Özdamar, K. (1999). Paket programlar ile istatistiksel veri analizi-1: SPSS-MINITAB. Eskişehir: Kaan Kitabevi.

Özdamar, K. (2017). Modern bilimsel araştırma yöntemleri. İstanbul: Seçkin Yayıncılık.

Pandey, J., \& Tewary, N. B. (1979). Locus of control and achievement values of entrepreneurs. Journal of Occupational Psychology, 52(2), 107-111.

Pathak, S., \& Singh, S. (2007). Developmental aspects of entrepreneurship. S. Bhargava (Ed.). Entrepreneurship and economic growth: The indian perspective (76-87). India: Sage Publications.

Peacock, E. J., \& Wong, P. T. P. (1996). Anticipatory stress: The relation of locus of control, optimism, and control appraisals to coping. Journal of Research in Personality, 30(2), 204-222. doi:10.1006/jrpe.1996. 0014.

Perry, C. (1990). After further sightings of the heffalump. Journal of Managerial Psychology, 5(2), 22-31.

Prakash, D., Jain, S., \& Chauhan, K. (2015). Supportive government policies, locus of control and student's entrepreneurial intensity: A study of India. Journal of Global Entrepreneurship Research,5(26), 1-15. DOI 10.1186/s40497-015-0042-7.

Ramírez-Pérez, H. X., Smith, A. M. E., Franco-López, J. E., Román-Maqueira, J., \& Morote, E. S. (2015). Journal of entrepreneurship education. I. Anitsal (Ed.). Effects of training method and age on employability skills of mexican youth entrepreneurs, 18(2), 125-135.

Raposo, M., \& Do Paço, A. (2011). Entrepreneurship education: Relationship between education and entrepreneurial activity. Psicothema, 23(3), 453-457.

Rotter, J. B. (1966). Generalized expectancies for internal versus external control of reinforcement. Psychological Monographs: General and Applied, 80(1), 1-28. https://doi.org/10.1037/h0092976. 
Rotter, J. B. (1975). Some problems and misconceptions related to the construct of internal versus external control of reinforcement. Journal of Consulting and Clinical Psychology, 43(1), 56-67. https://doi.org/10.1037/ h0076 301.

Sánchez, J. C., Carballo, T., \& Gutiérrez, A. (2011). The entrepreneur from a cognitive approach. Psicothema, 23(3), 433-438.

Schumacker, R. E., \& Lomax, R. G. (2004). A beginner's guide to structural equation modeling. London: Lawrence Erlbaum Associates, Publishers.

Schumpeter, J. (1947). The creative response in economic history. Journal of Economic History, (7), 149-159.

Shepherd, D. A., \& DeTienne, D. R. (2001). Discovery of opportunities: Anomalies, accumulation and alertness. 21st, Annual Entrepreneurship Research Conference, Frontiers of Entrepreneurship Research, 138-148.

Shepherd, D. A., \& Douglas, E. J. (1998). Is management education developing, or killing, the entrepreneurial spirit. In Proceedings of the 1997 USASBE Annual National Conference Entrepreneurship: The Engine of Global Economic Development, San Francisco: California.

Silvester, J., Anderson-Gough, F. M., Anderson, N. R., \& Mohamed, R. (2002). Locus of control, attributions and impression management in the selection interview. Journal of Occupational and Organizational Psychology, 75, 59-76.

Simsek, Z., Veiga, J. F., \& Lubatkin, M. H. (2005). Challenges and guidelines for conducting internetbased surveys in strategic management research. Research Methodology in Strategy and Management, 179-196. doi:10.1016/s1479-8387(05)02008-4.

Souza, G. H. S. D., Santos, P. D. C. F. D., Lima, N. C., Cruz, N. J. T. D., Lezana, Á. G. R., \& Coelho, J. A. P. D. M. (2017). Entrepreneurial potential scale: Evidence on confirmatory factor validity, dimensional structure and predictive effectiveness. Gestão \& Produção, 24(2), 324-337. https://doi.org/10.1590/0104-530x3038-16.

Strauser, D. R., Ketz, K., \& Keim, J. (2002). The relationship between self-efficacy, locus of control and work personality. Journal of Rehabilitation, 68, 20-26.

Sümer, N. (2000). Yapısal eşitlik modelleri: Temel kavramlar ve örnek uygulamalar. Türk Psikoloji Yazlları, 3(6), 49-74.

Şimşek, Ö. F. (2007). Yapısal eşitlik modellemesine giriş: (Temel ilkeler ve LISREL uygulamalarl). İstanbul: Ekinoks.

Tabachnick, B. G., \& Fidell, L. S., (2013). Using multivariate statistics (6th Edition). Boston: MA: Pearson.
Tarhan, M. (2019). Girişimcilik pedagojisine giriş. Ankara: Pegem.

Tavşancıl, E. (2018). Tutumların ölçülmesi ve SPSS ile veri analizi. Ankara: Nobel Yayıncılık.

Tezbaşaran, A. A. (1996). Likert tipi ölcek gelistirme klavuzu. Ankara: Türk Psikologlar Derneği Yayınları.

Timmons, J. A., Spinelli, S., \& Tan, Y. (2016). New venture creation: Entrepreneurship for the 21st century. New York: McGraw-Hill/Irwin.

Tuten, T. L., \& Neidermeyer, P. E. (2004). Performance, satisfaction and turnover in call centers: The effects of stress and optimism. Journal of Business Research, 57, 26-34.

Valdez, Z. (2019). The great recession and precarious wealth among middle-class mexican-origin entrepreneurs. Journal of Ethnic and Migration Studies, 1-18. https://doi.org/10.1080/1369183X.2019.1592879.

Venkatraman, N. (1989). Strategic orientation of business enterprises: The construct, dimensionality, and measurement. Management Science, 35(8), 942-962.

Wickham, P. A. (2001). Strategic entrepreneurship: A de ion-making app oach to ent. ( $2^{\text {nd }}$ Edition). London: Financial Times/Pitman.

Williams, G. C., Rodin, G. C., Ryan, R. M., Grolnick, W. S. \& Deci, E. L. (1998). Autonomous regulation and longterm medication adherence in adult outpatients. Health Psychology, 17(3), 269-276. doi: 10.1037/02786133.17.3.269.

Williams, J. G., \& Stack, J. J. (1972). Internal-external control as a situational variable in determining information-seeking by Negro students. Journal of Consulting and Clinical Psychology, 39, 187-193.

Yıldırım, A. ve Şimşek, H. (2016). Sosyal bilimlerde nitel araştirma yöntemleri. Ankara: Seçkin Yayıncılık.

Y1lmaz, E. ve Sünbül, A. M. (2009). Üniversite öğrencilerine yönelik girişimcilik ölçeğinin geliştirilmesi. Selçuk Üniversitesi Sosyal Bilimler Enstitüsü Dergisi, 21, 195203.

Yukl, G. A., \& Latham, G. P. (1978). Interrelationships among employee participation, individual differences, goal difficulty, goal acceptance, goal instrumentality, and performance. Personnel Psychology, 31(2), 305323. doi:10.1111/j.1744-6570.1978.tb00449.x.

Zhang, D., \& Bruning, E. (2011). Personal characteristics and strategic orientation: Entrepreneurs in Canadian manufacturing companies. International Journal of Entrepreneurial Behavior \& Research, 17(1), 82-103. doi:10.1108/13552551111107525. 


\section{Extended Abstract}

Introduction: Entrepreneurship is one of the important factors contributing to the growth of national economies. It is seen that academics have individual efforts towards entrepreneurship in order to adapt to changing conditions. This research focuses on internal control focused entrepreneurship, an important component affecting entrepreneurship. In this direction, the problem of the study is developing a scale to measure the proclivity for internal focused entrepreneurship of academics who have played important roles in the production and transfer of knowledge and the advancement of science. In this study, the subject of entrepreneurship is investigated from an internal control focused framework, which is one of the entrepreneurship characteristics. A scale was developed to evaluate academics' proclivity for internal control focused entrepreneurship In that sense, it will contribute to the field by evaluating the entrepreneurial dimension, which is a necessity for a third generation University. It is seen that academics are making entrepreneurial efforts in order to adapt the changing conditions. In order to get more efficiency out of the academics who are playing an intermediary role in the management of this transformation process, the functions of higher education institutions should be evaluated within the framework of academics' entrepreneurship . Entrepreneurship plays important roles in national development as well as in the establishment and development of organizations (Bhole, 2007; Dayal, 2007; Hisrich et al., 2016) and it conceals important connections between cultures that shape modern life. In this way, it makes a significant contribution to ensuring social and individual well-being and raising the living standards of individuals. When the literature is reviewed, it is seen that cognitive awareness, autonomy, self-efficacy, the quest for success, searching for and making use of opportunities, taking risks, pro-activeness, innovativeness and having locus of control are among the character traits of entrepreneurs.

Methods: In this study, screening model from quantitative research methods was used. In the process of scale development, literature review, sample pooling, reviewing expert opinion and pilot implementation steps were followed. The research universe consists academics working in universities in Turkey. The sample of the study consists of 571 academicians selected from using simple random sampling method. During the validity reliability study, exploratory and confirmatory factor analyes were made. The scale was applied on 291 people for exploratory factor analysis. The measuring tool for which corrections were made after exploratory factor analysis, was applied on 280 academics.

Findings, Discussion and Results: This study is a scale development study that examines the concept of entrepreneurship (Pandey \& Tewary, 1979; Valdez, 2019; Wickham, 2001), which is accepted to support entrepreneur personality in the development of opportunities, entrepreneur attitude and behaviour, with an internal control focus perspective. Before applying factor analysis to the sample form in order to asses the academics' proclivity to internal focused entrepreneurship, KMO and Bartlett tests were used for investigating the applicabilty of factor analysis. During the validity reliability study, exploratory and confirmatory factor analyses were made to find out construct validity. During factor analysis, principal component analysis was applied using varimax rotation method. In determining the number of factors of the scale, slope deposition graph was examined. In order to ensure its reliability, cronbach alpha coefficient values were taken into account to determine the internal consistency of the structure to be measured. "Internal Control Focused Entrepreneurship Scale" which was developed as a result of the study, was established as 27 items in a 7-Factor Structure. The dimensions determined for the internal control focused entrepreneurship scale are found to be originality, autonomy, control, quest for success, risk-taking tendency, pro-activity, searching for opportunities and recursion. According to Carland and others (1984), entrepreneurial individuals have a high motivation for Success, Take moderate risks, innovate, and have a focus on internal control. Lumpkin and Dess (2001) found that innovative or new venture activity suggests a forward-looking and proactive perspective. When studies are reviewed, it is seen that the 7-dimensional structure that is developed supports the literature. The determined factor structure of the Internal Control Focused Entrepreneurship Sample was tested with confirmatory factor analysis. As a result of the analysis, it was determined that the agreement statistics calculated by confirmatory factor analysis are compatible with the previously determined factor structure of the scale. When standardized coefficients are examined, the validity of the structure regarding the predetermined factor structrure was confirmed. In order to determine the distinctiveness of the scale, a distinctiveness analysis was performed, and as a result of the analysis, it was determined that the scale made a distinctive assesment. The cronbach Alpha coefficient for the internal control focused entrepreneurship scale was found to be very high at 0.894 . This values were founded; Authenticity size; Alpha $=0.852$, control size; Alpha $=0.759$, autonomy size; alpha $=0.749$, quest for success size; Alpha $=0.737$, risk taking tendency size; Alpha $=0.769$, pro activity - searching for opportunities size; Alpha $=0.788$, self-efficacy size; Alpha $=0.801$. According to the data obtained, it was determined that the entrepreneurship scale focused on internal control has validity and reliability that can measure the entrepreneurial tendencies of academics. With the developed internal control focused entrepreneurship scale, entrepreneurship can be made known, understood, embraced especially in higher education institutions and tendencies for entrepreneurship can be identified. In order to achieve wider and more beneficial results, the scope of areas that will create awareness can be expanded by addressing academicians ' entrepreneurship with different variables such as personality traits, leadership skills, and corporate culture. By conducting interviews with entrepreneurial academics, the subject of research can be addressed by qualitative methods. In addition, more extensive research can be done to determine the difference between cultures of entrepreneurship in higher education institutions. 